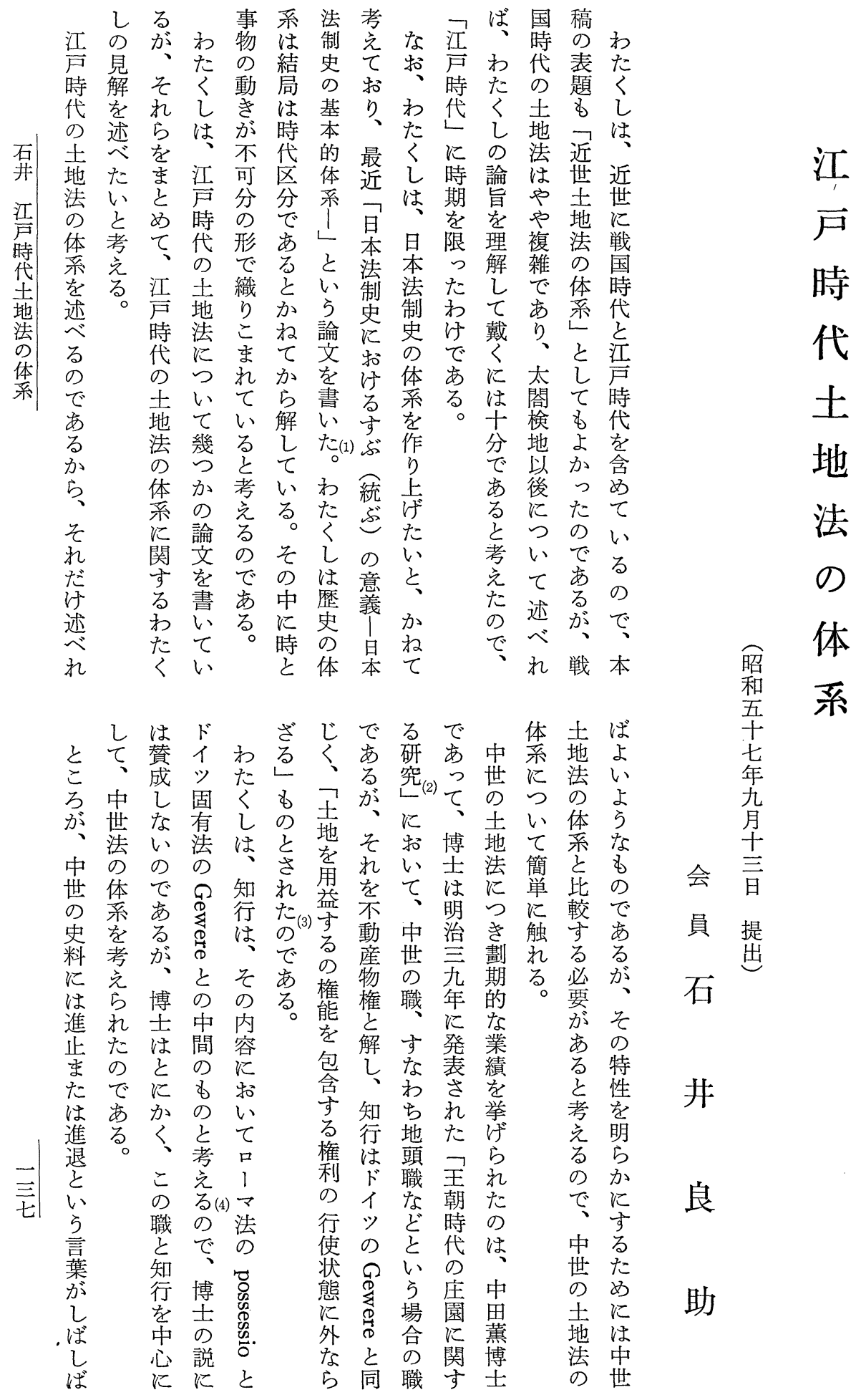


日て分いけでとく考它るばほ広光止で見 本考将 ら

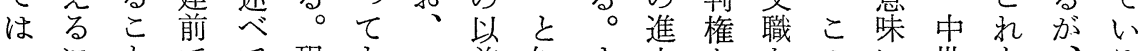

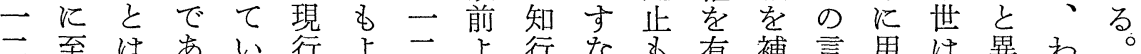

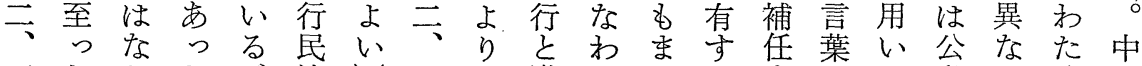
三たかたが法し三の進らたるるす寸はた私りく田 世のっか、での世考退、中こる裁の混、吼博

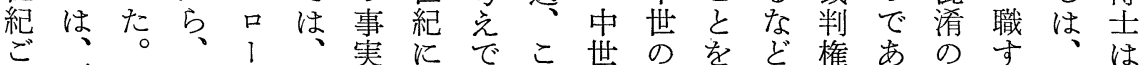

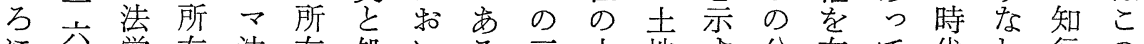
に公学有法有処いる(7) 三土地す公有て代わ行の

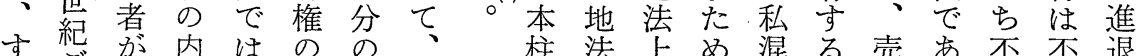
でご所容所内権権少法重に看庄却る動動を によ有を有容能利上職要名的園尘産産知 所を権使権を索々 の にこな用なの贈ら物物行

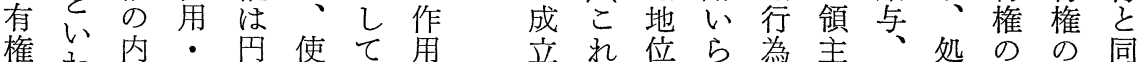

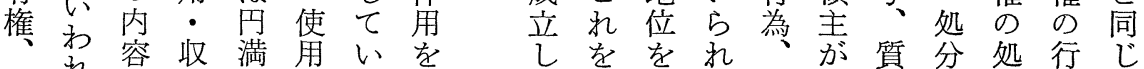

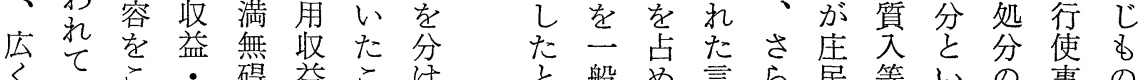

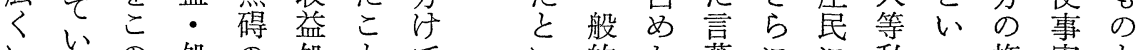
いるの 処の 処々てい的た葉にに私っ権実と

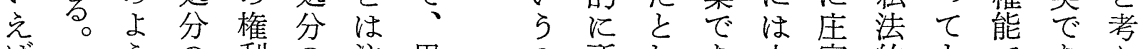

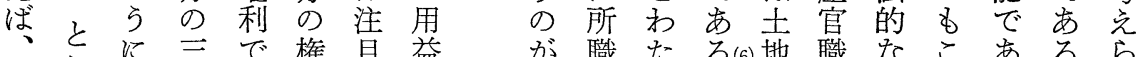

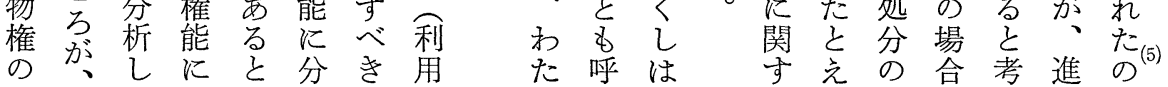

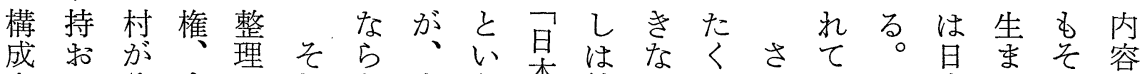

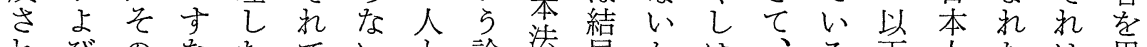
れびのなたでいと論法制局かは市人たは用

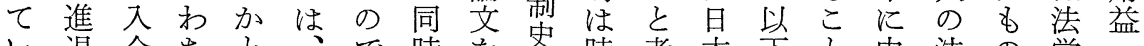

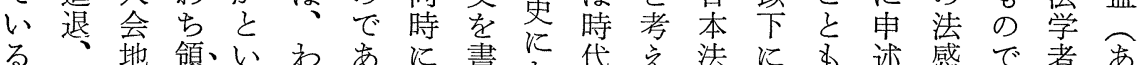

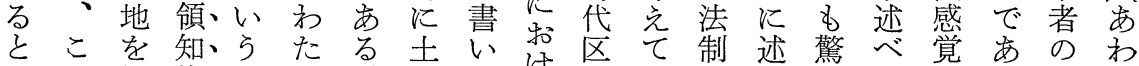

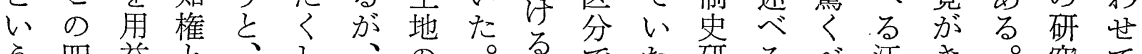

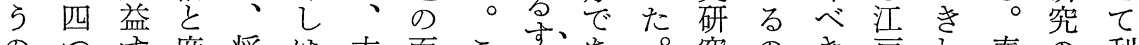

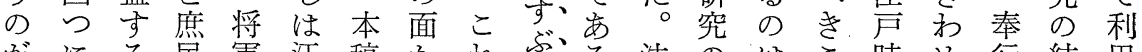
がにる民軍江稿かれぶる法のはこ時め行結用 わよ進のの局はらは統之制初、之代ての果亡 たつ退土大時そ見主ぶ考史め江だの鋭知です

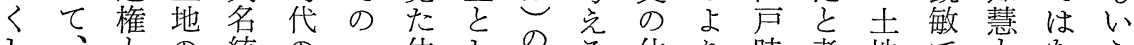
し、との統、の—体しの る 体り時考地で音なる

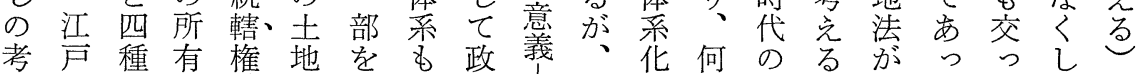

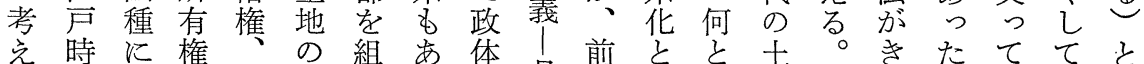

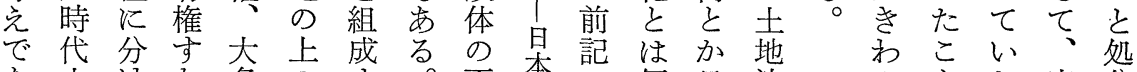
る㐫地るお名 の る地る わ の

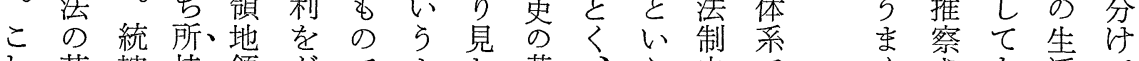

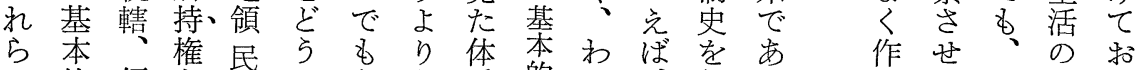

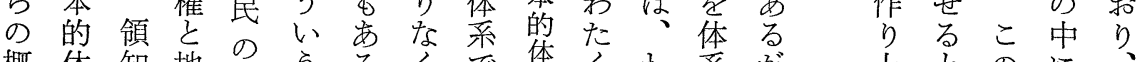
概体知地系支風。方

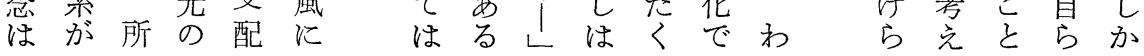




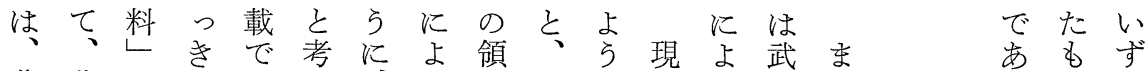
幕幕とりは光学国中で在っ家ずするす

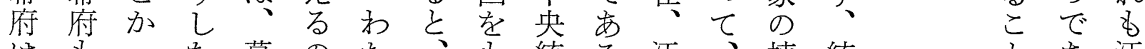

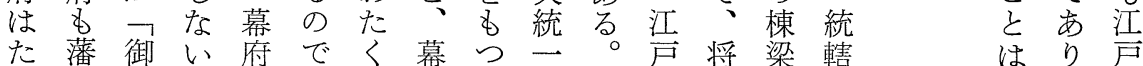

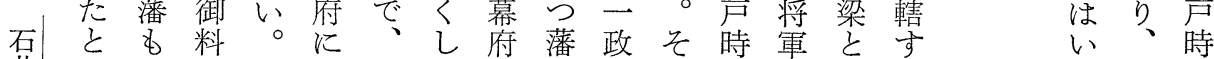

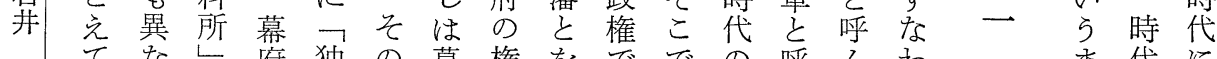
江てなし府独の幕権をででの呼んわ 㞋 5 な 代之かっ轄領ら権統機江藩体之軍 圭諸た 法大が自知にの統権し府と称る正名

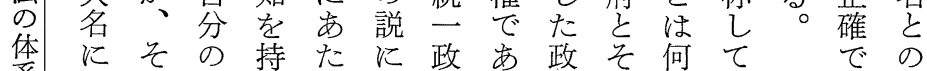

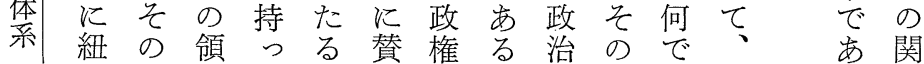
を間知ても成它支体支幕幕係

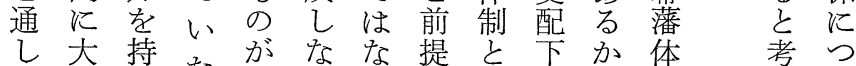

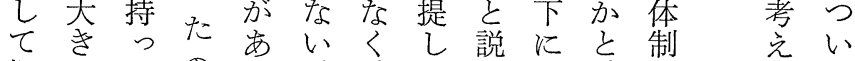

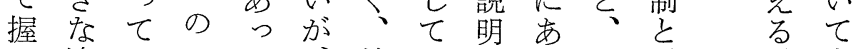
て違いでた 、統い方方国呼㤎申

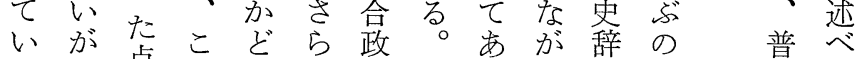

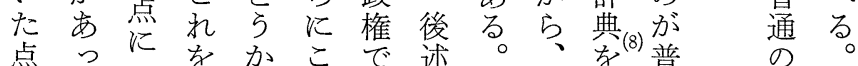
点た技てがの市のこ独自通用将 あのい御は記るよれ立るの例軍

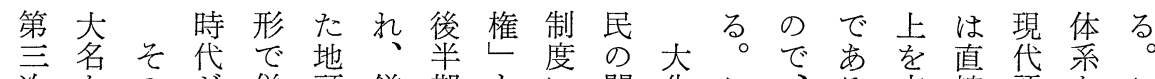

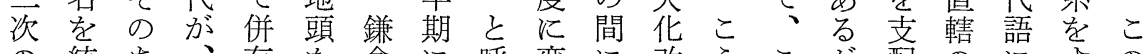

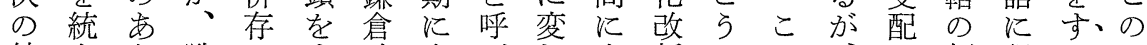
統合と戦し す 時京びお立新い方、領訳ぶ、こ 合导に国たべ代都、っ紊にう関上、地しをと 政る村時がる(10) の統たをな政係代こをて用を 体村を代、と注天統。いっ体にでれ持、い古 で落基で両いこ皇拿こうてをるはをうわて語

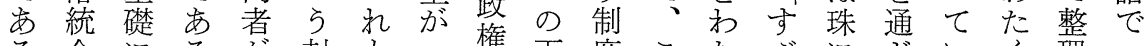
る合にるが封と庄権天度こたぶにじいく理 。政す。い建並園子皇はのくし紐てたししす

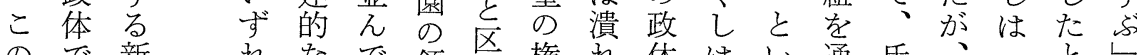
ので新机なで領別権机体は心通氏、衣し

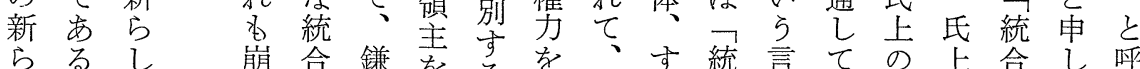

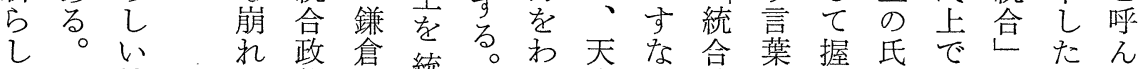

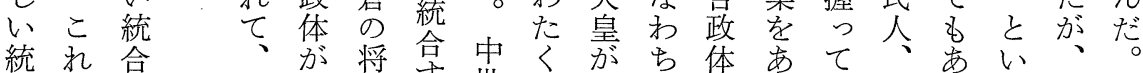

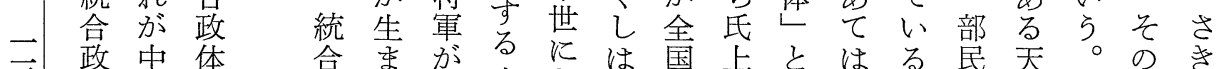

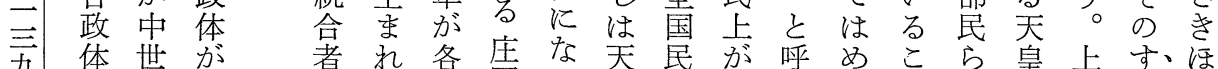

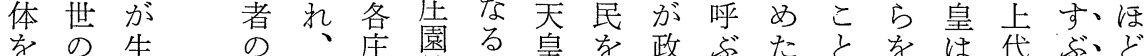

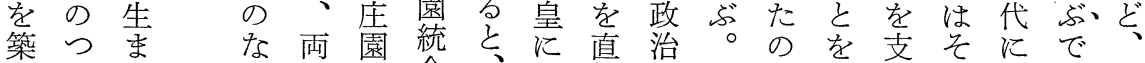

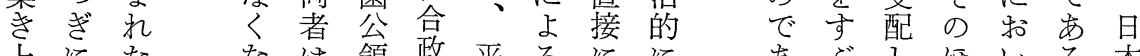

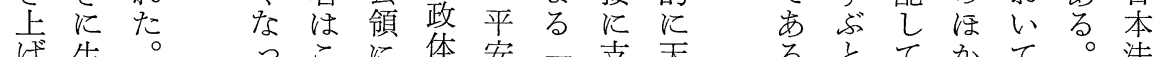
た生将た た の机軍分い少生代寺圭考口たの氏ぶ、史 がたが国られ亦の政る国党たの氏上をの 


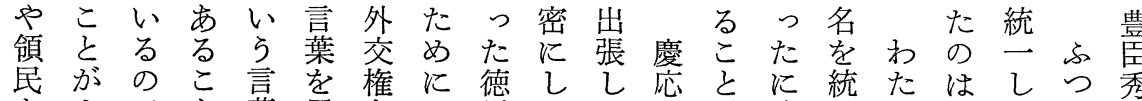

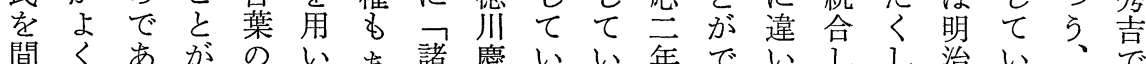

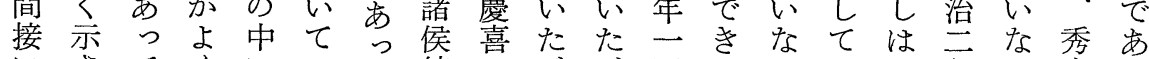
にさて、にいた統に思㤎四たいいこ年い吉る は机、示、るの轄大、、代。をたのの。は。

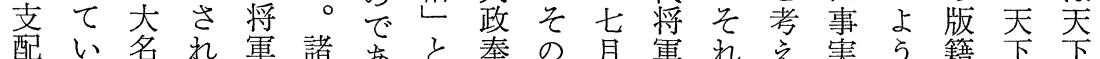
乙る(1)のての侯るい還間に徳がてをに奉のを

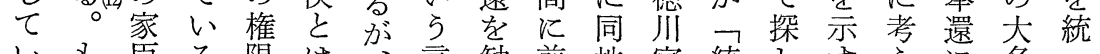
いる臣る限は、言勧前地家統し寸放名一 たちや。は奇々葉告越で茂轄て言たょをし

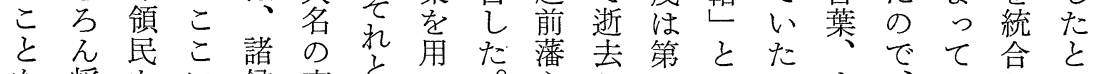

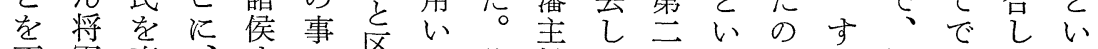
否軍直、寸で別てそ松た回らでな江あたわ 定は接将なあ别いの平。長言あわ局る(1)のれ す大軍わるてる中慶幕州葉るる 時。でて る名は岕かて。で永府征でが統代尔い

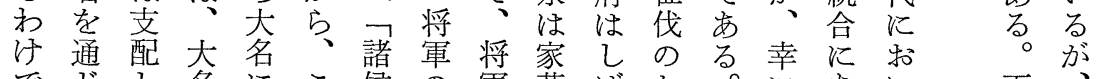
でじし名にこ侯の軍茂ばた

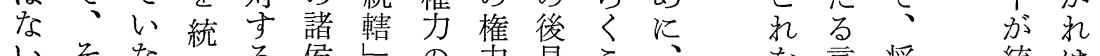

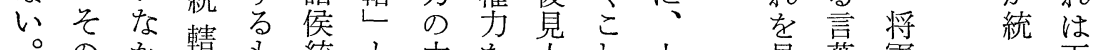

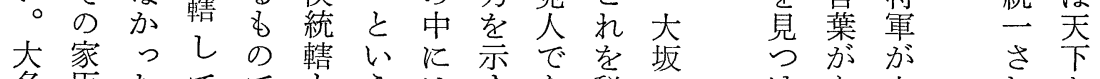

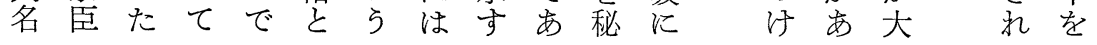

さて

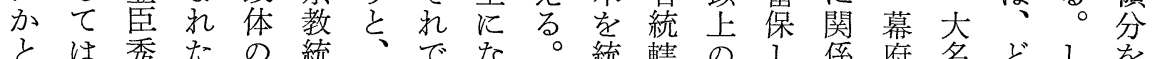

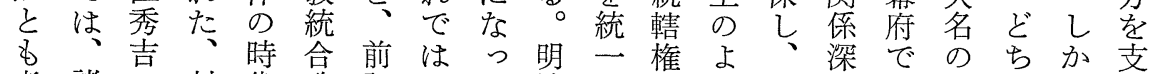
考諸は封代政記こた治国をらをい裁間らし配

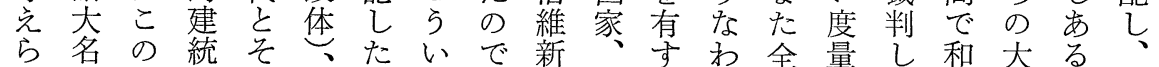

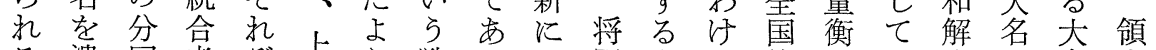
る潰国者ぞ世ら戦るよ軍大で的のいす名古

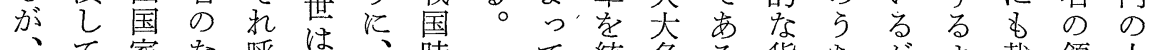

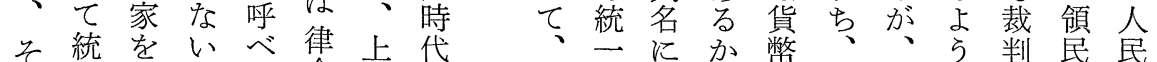

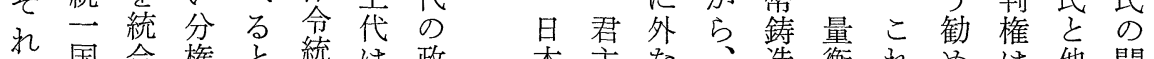
机国合権主統は政本主な造衡れめ他間 で家し国考一第体は主ら将権火はてなのの はとた家爷政一は解な軍をつ特いい大訴

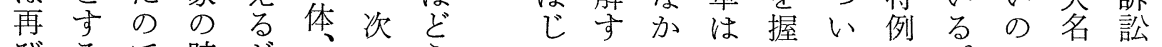

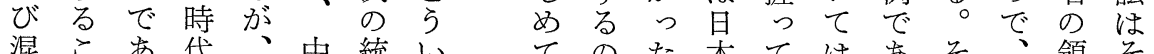

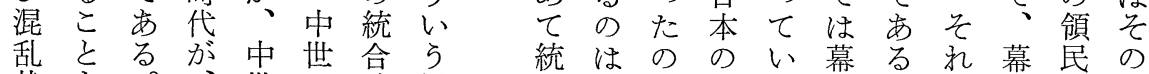

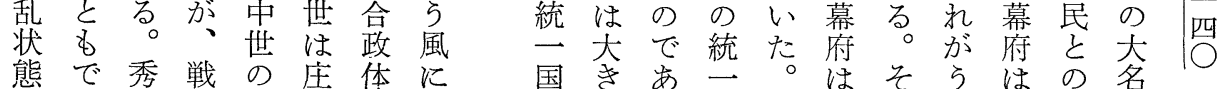

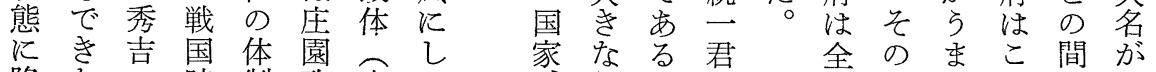
陥なの時制政丙七誤。主国注くう裁 るい実代が体容で天り江沓的かいい訴判 危で屴でく:的き皇で局は年から訟し

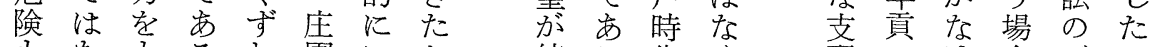

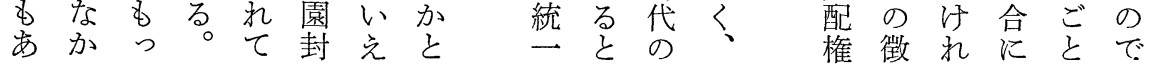




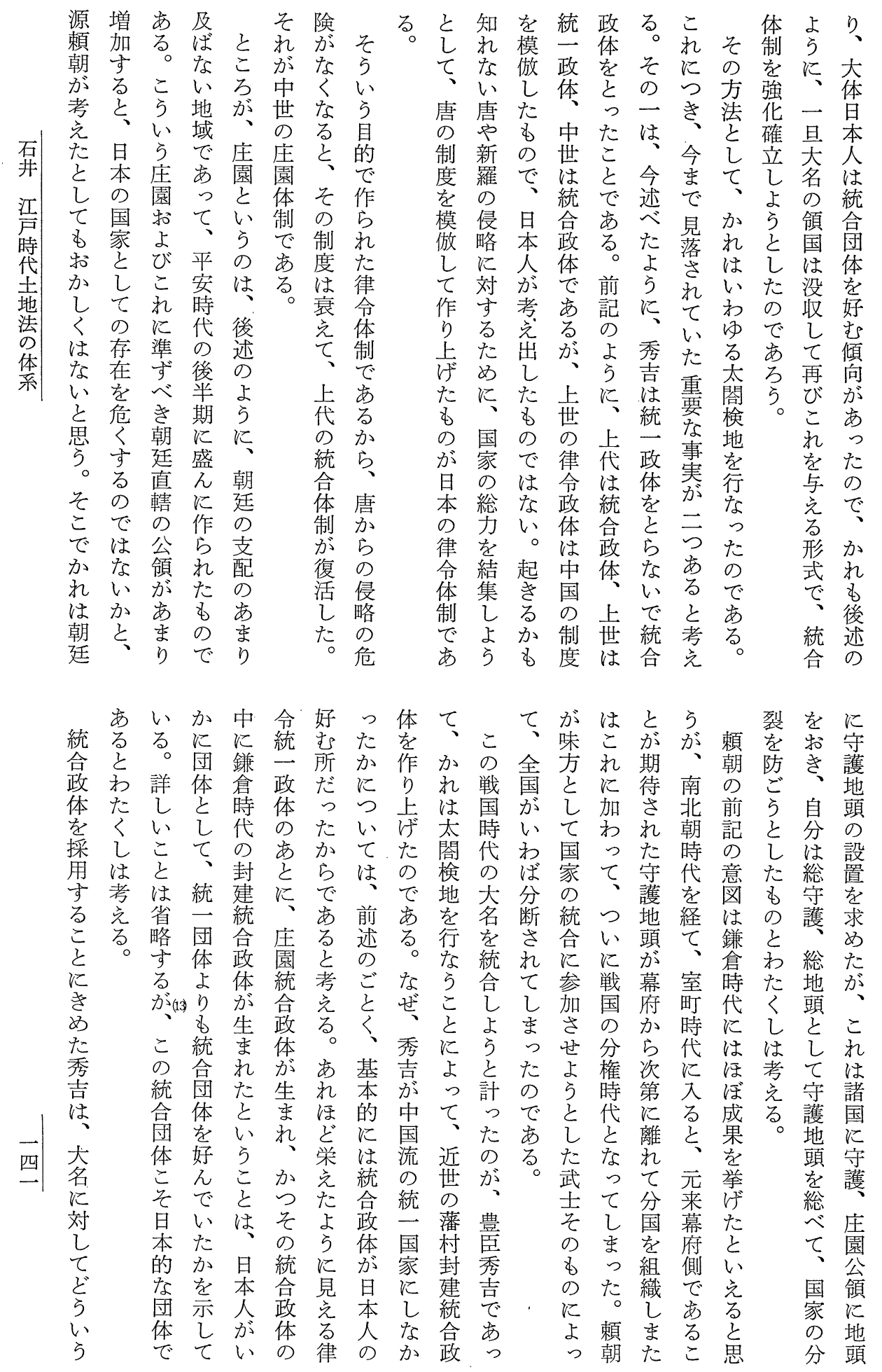




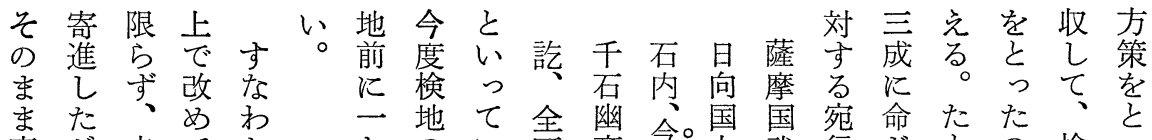

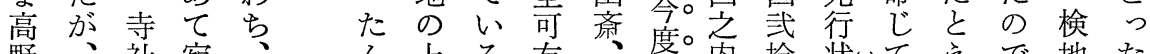
野、社宛、上る有、度。芮拾状(14)てえで地た

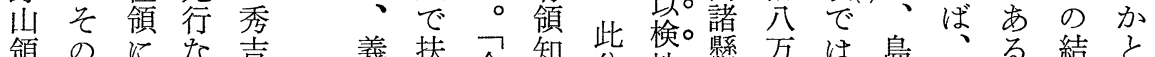

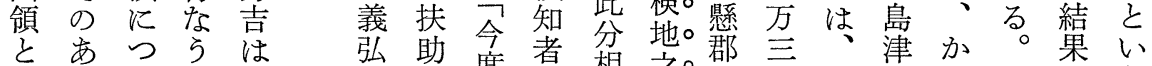

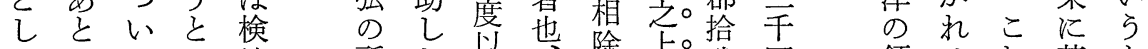
$\tau \tau ゙$ 地 扱調的 万比 わ心゙同政よ れて様策り てみでを大 いる范名 ると口っ ど を机秀では

知以吉あ一 っ前はるた たの高。ん 秀旧野こ没 吉領山れ収

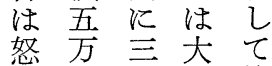
怒石京名検 て余石領地

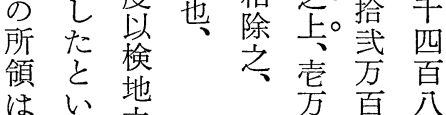
没少势五石分拾 収の京拾御拾分 さで 梦市令入石 たる扶杂六合隅 らら䚺五武吾国

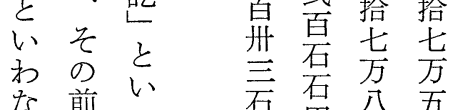
な前っ 石累分五 れとて 蒱唋治七五 ばしい南㐨部帛拾 なて、の 令。輔参吉 な検は劮。参参 領杜叔基衣 国齐禄よ 検至只机 地年て必 さ津合な名 せ義体らの て弘制ばそ いのの改れ る朝強め高 が鮮化てで 、出を与の 翌陣計兄領 年のっる地 そ際たとは の 飞字 い二 義只らた 弘石古方等 に田考策没

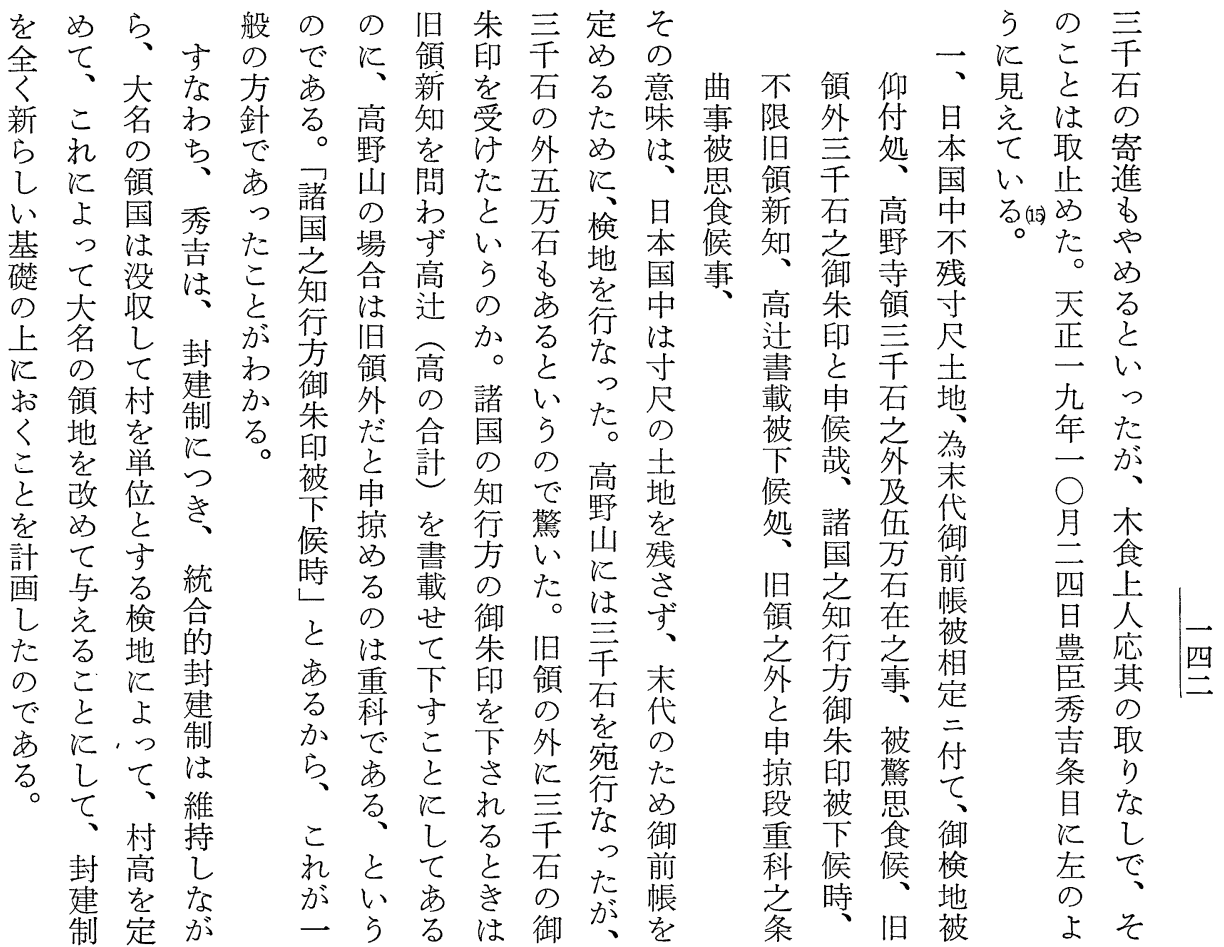


たるら藩い同地ヶ二れ行と取わ

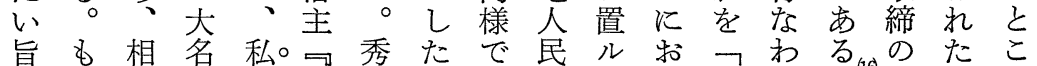

願つ続の八。池吉があを、い預れが法もる

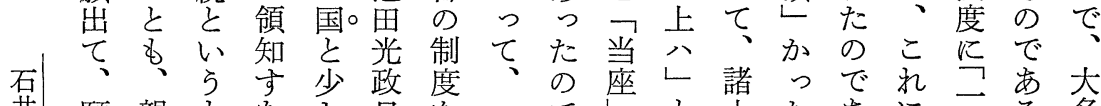

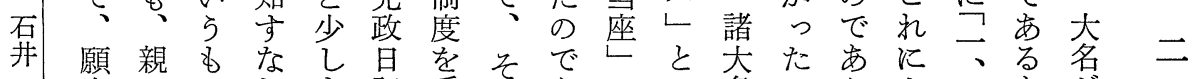

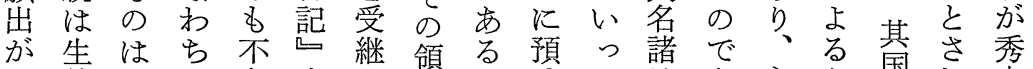

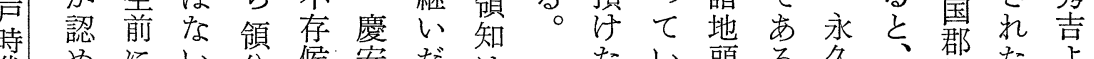

代めにい分候安だ祖たい頭る久方郡た高

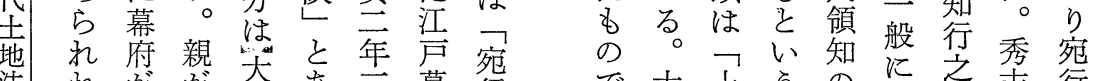

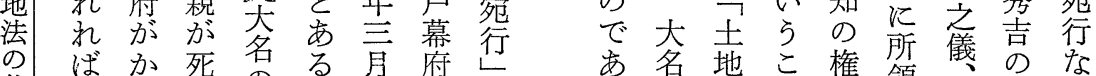

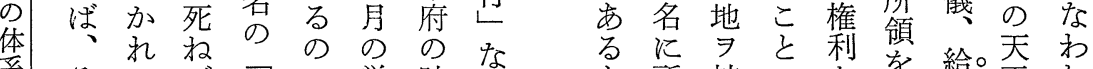

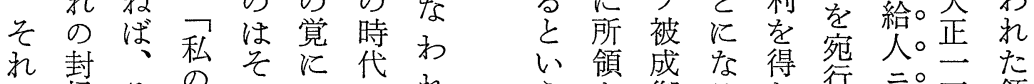

は禄々国の故当でれ

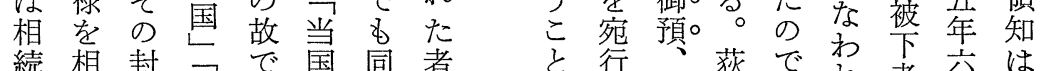

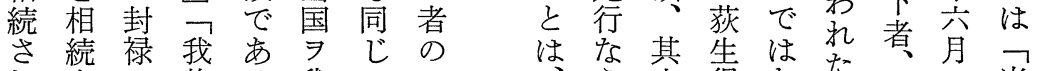

れ人性る我で我物主徂な者当坣

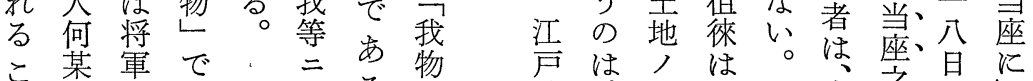

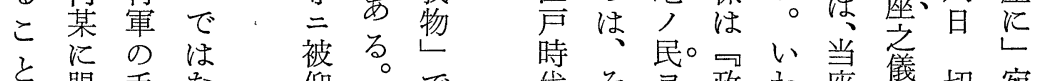

と賜手な仰。で代そ年政方莝儀切宛

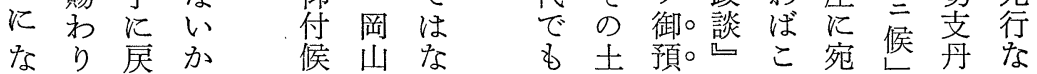

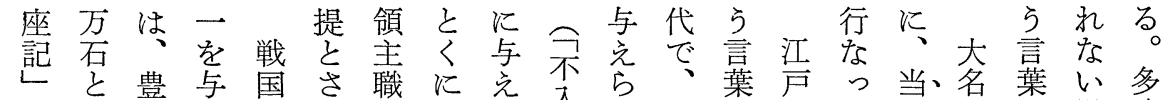

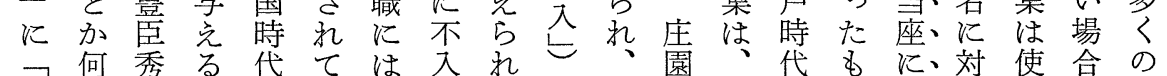

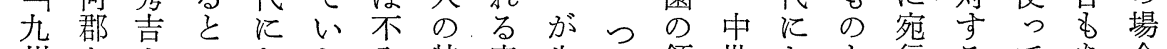
州をいい扝た入特庄生い領世抗と行るて市合 御与 り 5 け の の権園玉で主でいさと領いりに 国爷よるで権をのれ、にはてれい分た尝は

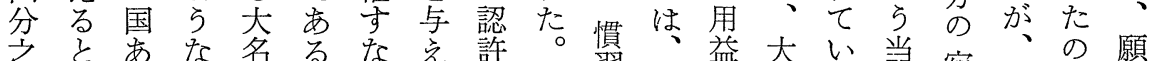

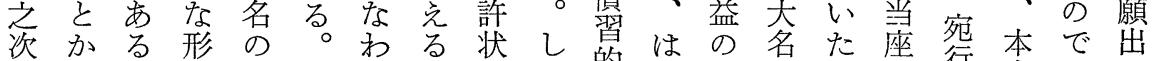

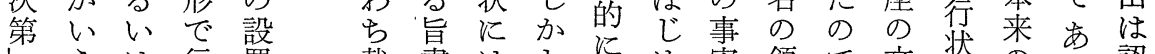

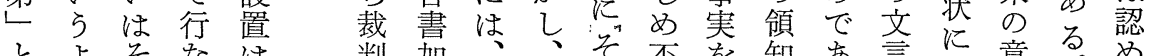

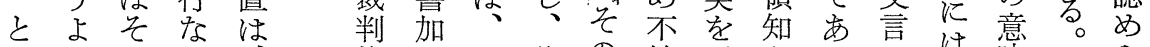

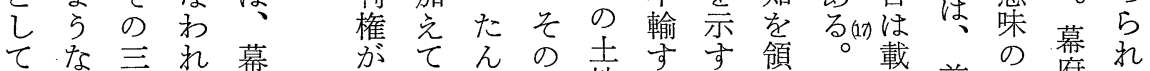

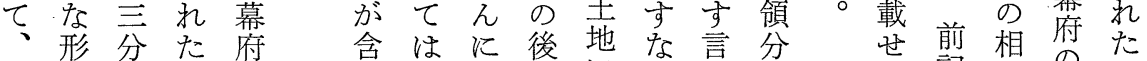

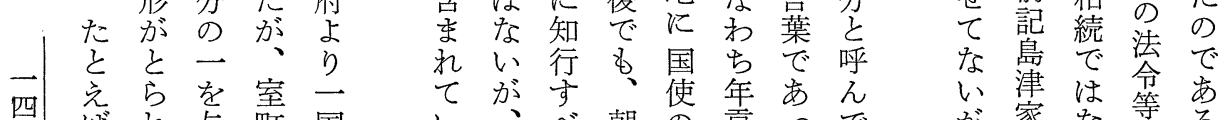

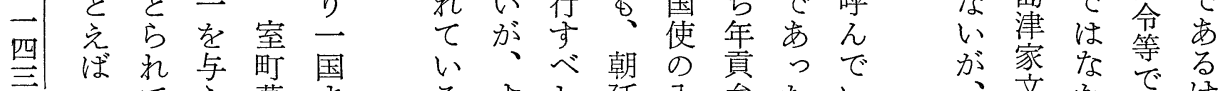
ばれ与町国い、へ朝の貢っで学家な等る

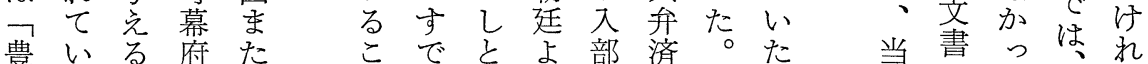

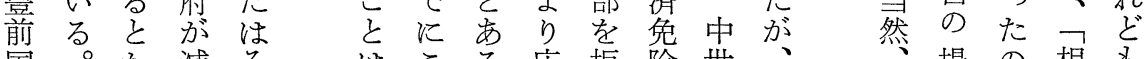
国。か滅々化こる庄拒除世場の相名

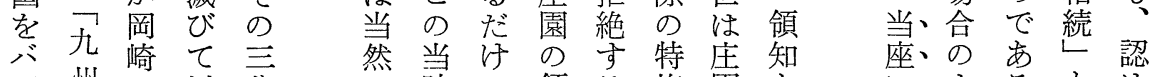
分州動五後の分 前時で領方権園々 


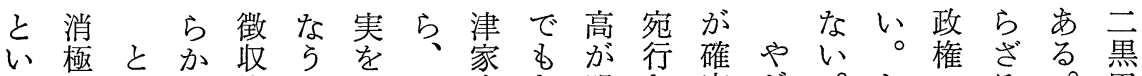
う的こで権と示こ齐な明な定が。か乍思

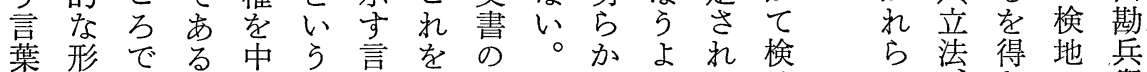

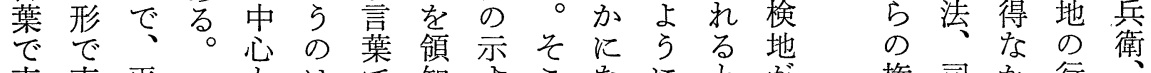

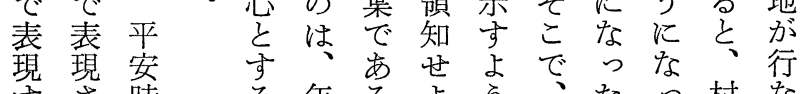

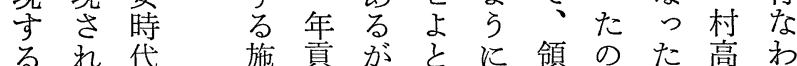
るれ代施貢がとに領のた高わ

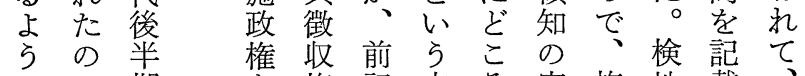
にで期学権記文年宛施地載

なあで与だし言こ行政のし一 る当注た架に状上結て村

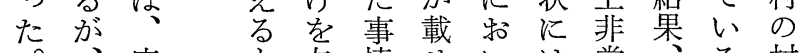

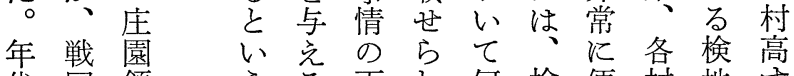

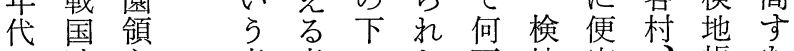
は時主意意飞た方地宜、帳な 不代の味味背何の洛をわ 明の施㐌で何領千結な郡基ら 灾政严は方知石果っ 、礎一 るに柱くな元宛基こ国し内

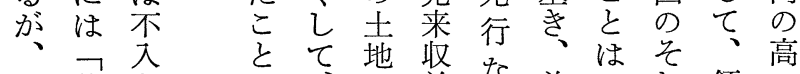
四在々 注文地益な前い机領高 月置い年宛のう記う染知合 権司か行法っな 利法さなお 庄行 の㨬森 の紫い壱 領をるな岐 主 机意に繁公 每だ㤎い候 でったて事第 っこ貢、と たと徵こあ と双方年 はい権いの 考らをらは 充含形々 えでめ式の ら 8 て 例

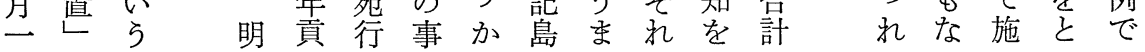

せに内た 戸っはのをも結がの行をら被六 て努にめな幕たな封相々果各で以に仰知定星

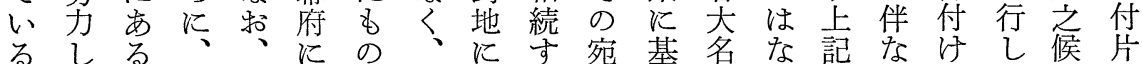

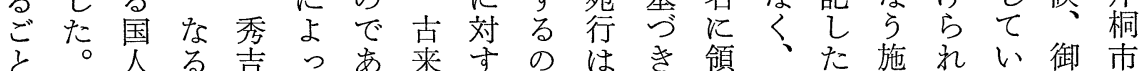
き九勢たはてるのる権当新知全こ政たた仕。正

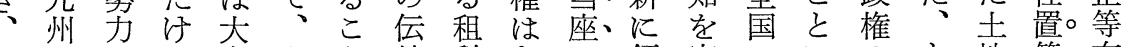
そのと大名大と統税なの領宛のにのと地等在 の島の名と体はに徵か子地行大よ意いで可判 顕津関をそ受明ょ収っのを名っ味ら少被の 著家係転の継らり権たで宛ら染てでのる仰知 なのを封旧がか、をこあ行とか、あでが付行 例領断さ領机飞仕得々り机 で国ちせ分たな置だ、うは豊こるそし目

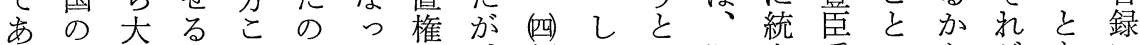
る検名方とでたへ、領たい旧合秀はらがあに 地の針にあ 立飞地がう来さ吉明、こる。

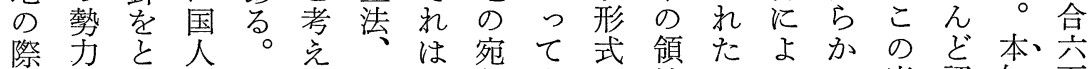

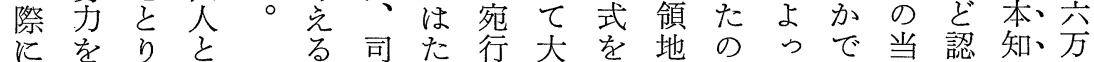

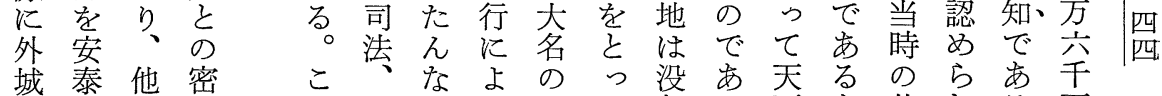
をな面接和行るる子た収る下仕机る石

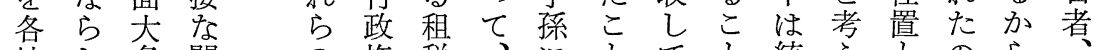

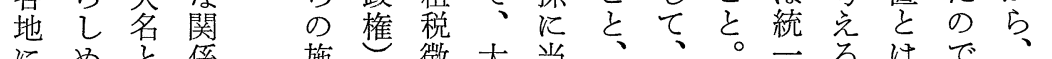

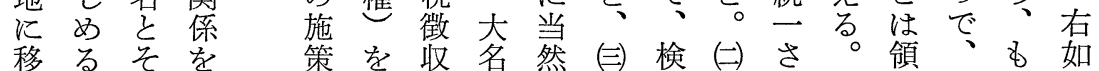

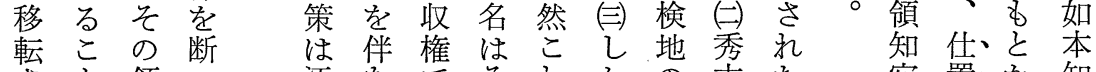
さと領つ江なでそ水かの吉た宛置か知 


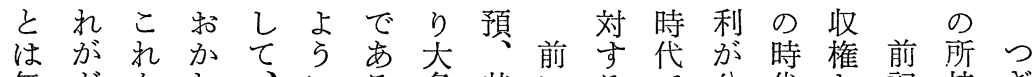

無どをれ、にる名其にるで公代拉記持ぎ

関こ無た大ながに去む所は的でよのにに、

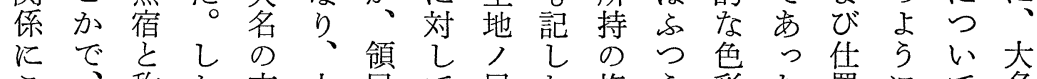

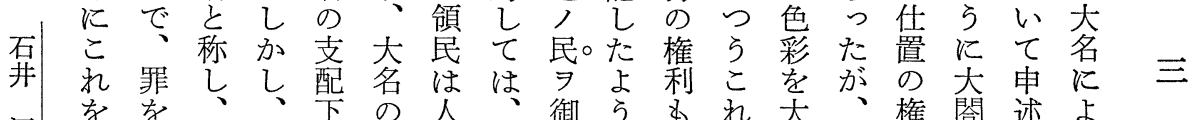

江をを、下の人、御ら省を机、権閤述よ

望処犯大犯に領別土預に私をいこ利検心゙

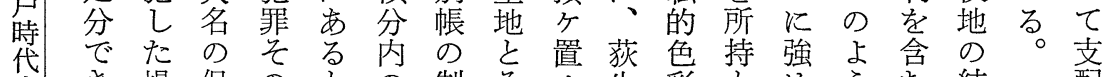

帒き場保の と

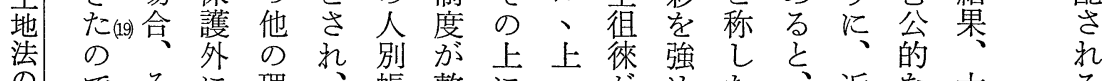

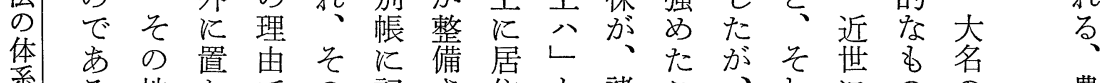

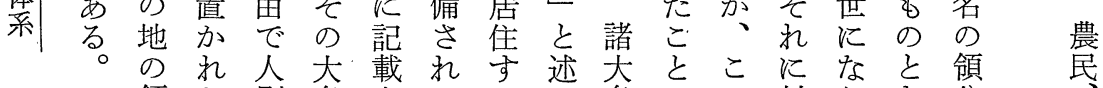

領た別名さるる心名にの対りな分

主の帳の就領て地な庶す大江町

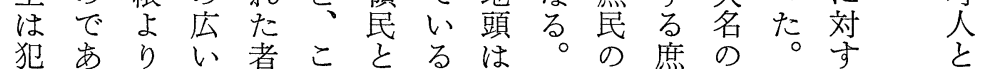

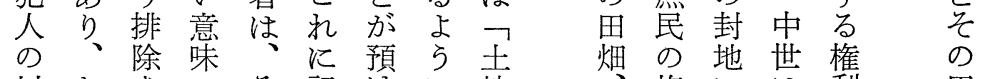

以たさのそ記汻地権には利田

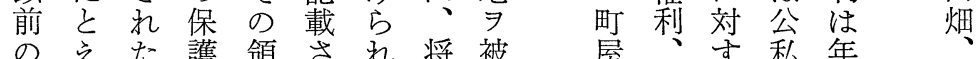

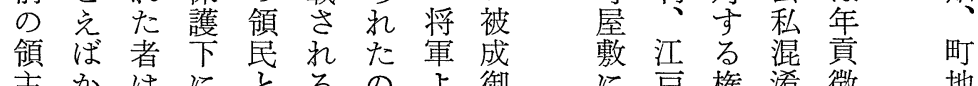

主かはにとるのよ御江声権淆徵地

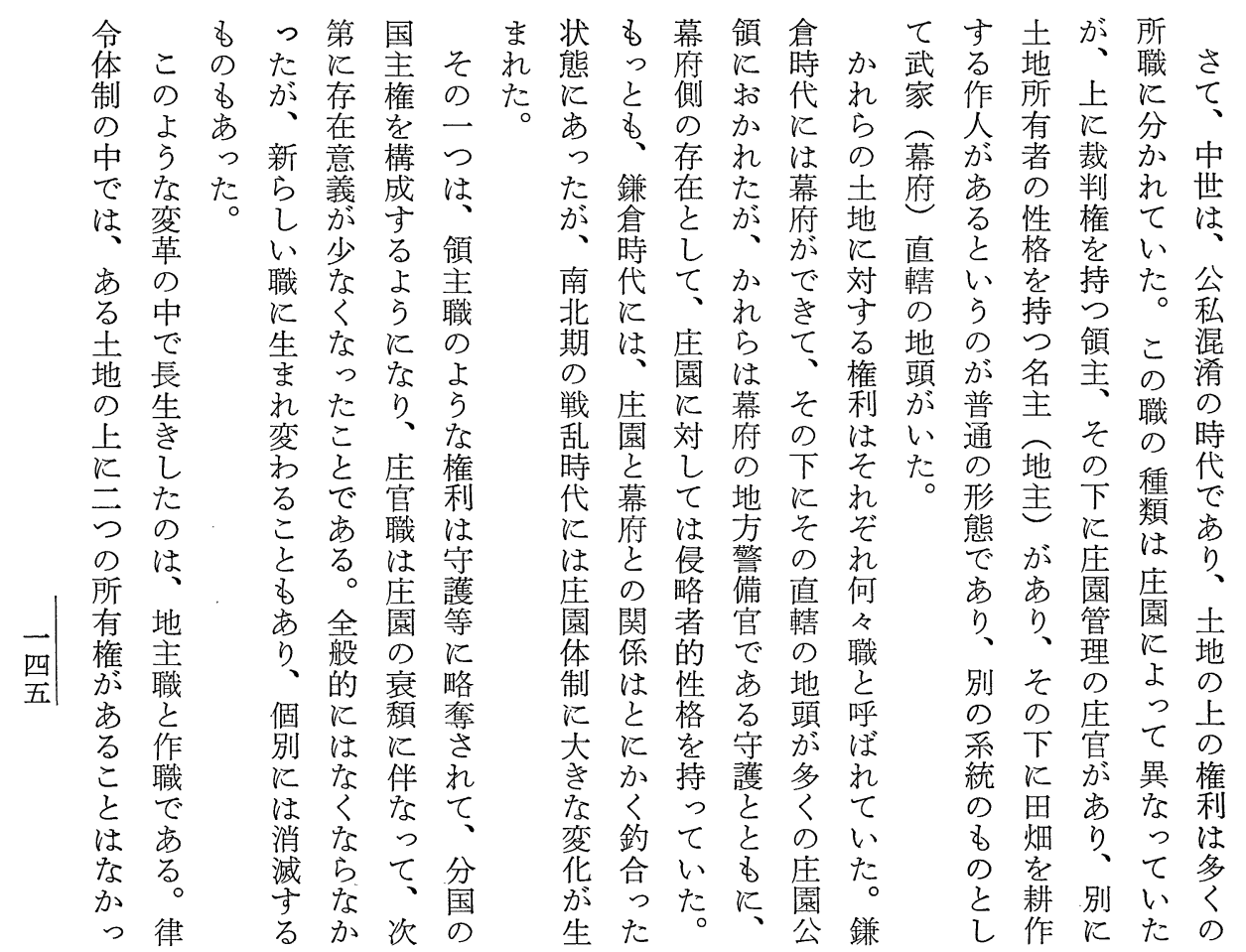


職つわた建生た職

を地机例武じ地 持作てが至た主作の っ上いあ年。職職よ て共たるのそととら いにのか東れ作がに て譲でら龺は職主し 他受あ、寺交要て

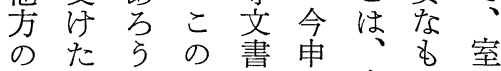
権々。傾でし庄の町 利い応向はた園で中 をら永は、地衰あ期 譲記一鎌作主類っ以 受録二倉人職期た後 けが年時がとにのも たあの代作作入で庄 のる東の主職るあ園

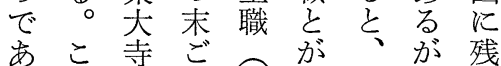
万の文万作合元、只 ら父書に職併の庄た 。はには卞形園職

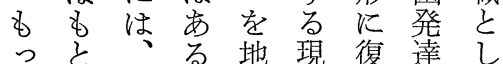
之地父程主象守期て 主の度にでるには 東職手法去傾分地 大寺作り行渡る。向離地
しらる庄地名者あた 、にと園主主㤎るの まな、のと堹程で たっ名中い呼ま度あ はた主にわぶれのる 性。る生机こた公が 四 格他り㐬て主権平 変庄面尔は何—新を平 園以字般乙持 たの 前のわ化いよ代 衰のでかし地ら地あ に主るな。でな以 伴子かい鎌ある後 ないらく倉冢文 いら、ら時が

庄言庄い代、々 園 官葉園でに平の唯 職がのあは安庄発 $も$ 復衰っ名時園達 前活 頽た主代のし 記しし。 の の 中た のてたし語末に ご使室か唯新庄 之用町し普らら園 くさ時、及はしの 減杂代名元こ領 減る

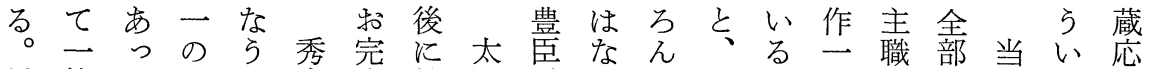

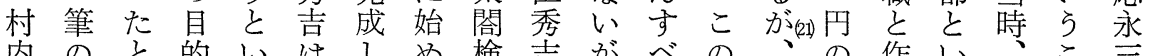
内 の $内$ 的 高地光大宛名か、はょこの象のらと意ばもの

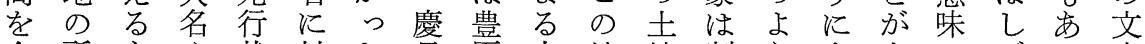
合所々や状対た長臣太地地割う合合でばっ書 計在考寺をしも言秀閤作に合に体体あててた す、社出ての年吉検二つにつすてる地のは

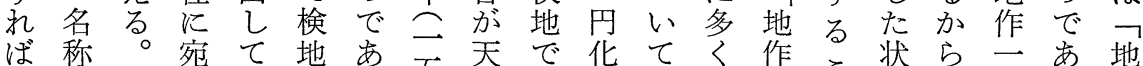
、検行いの る 五正あを、行二を態、円主

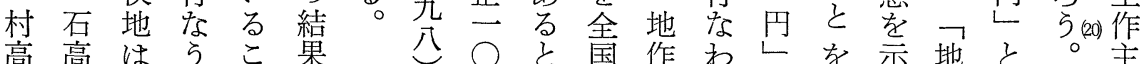

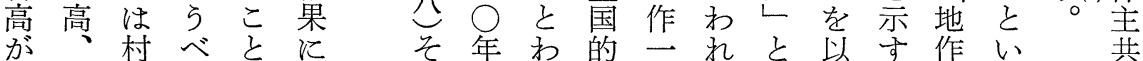
得名ごきか基 のこた規円たい前も五ら列 ら請と土らら゙ 死吾く模化も方よの円言 買 れ人に地もき吾しでのの言りでし葉得

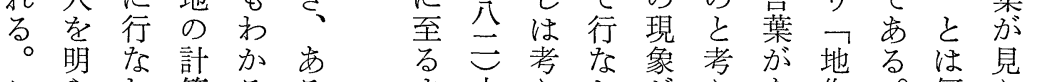

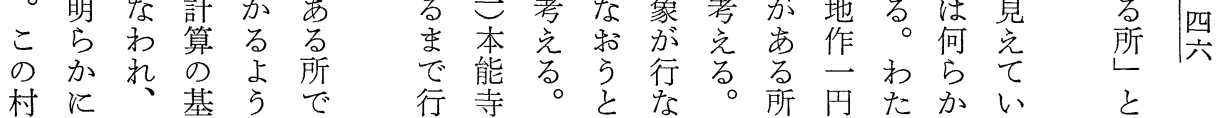
高高土礎侍何なの方しを化くのる

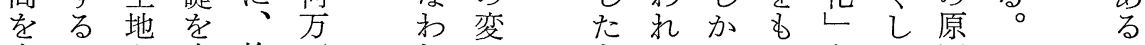

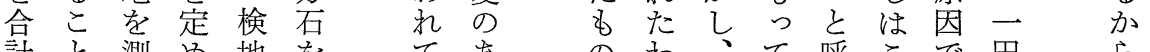

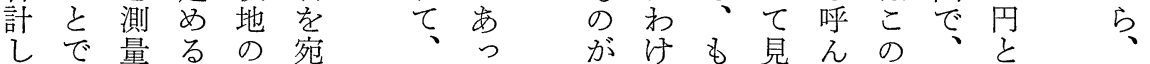

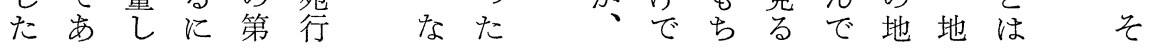




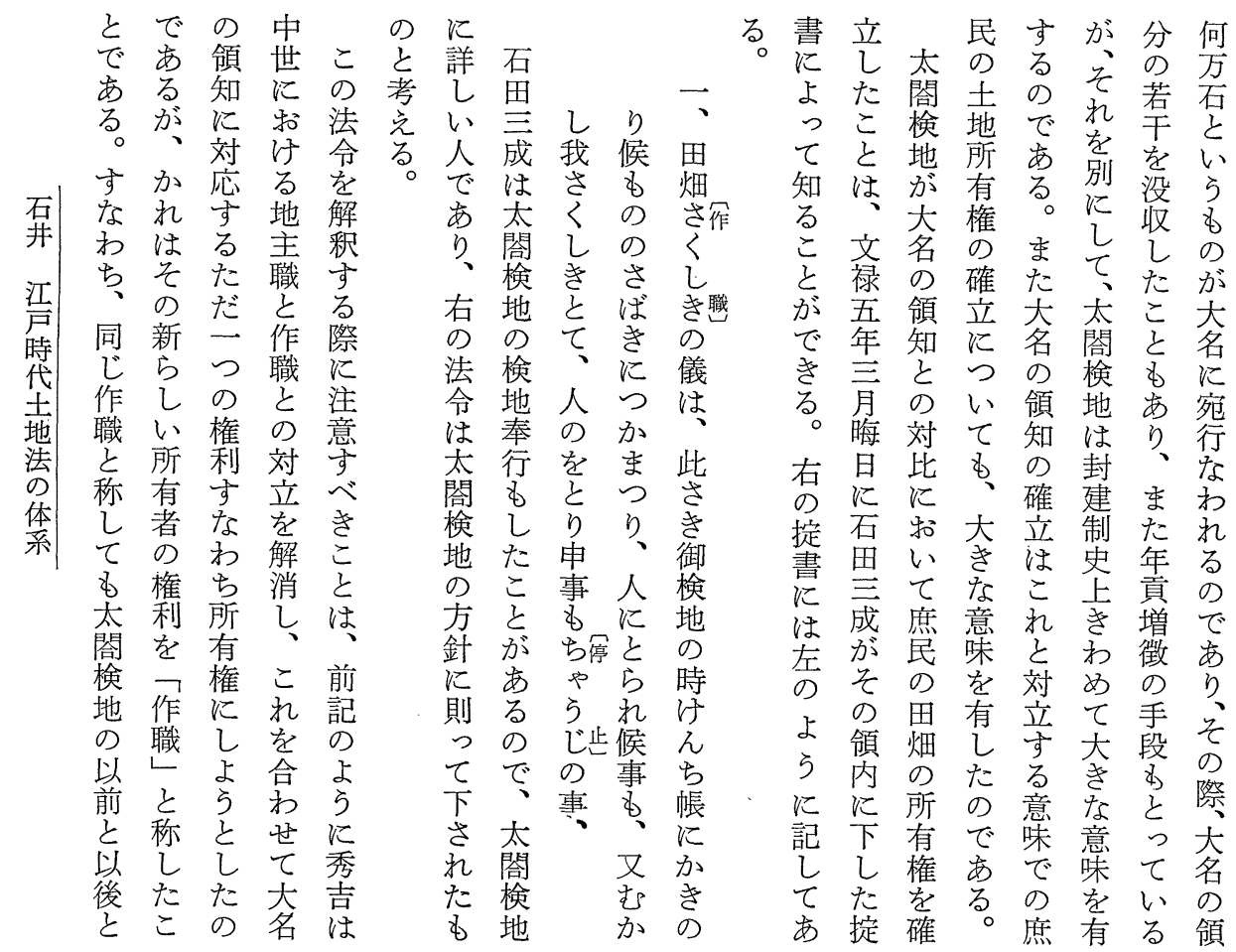

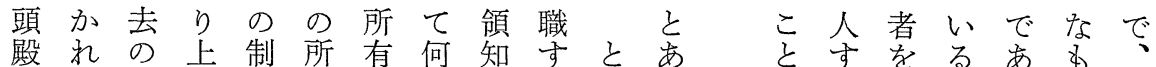
秀は翌げ度有地方になにる、はな作者る。の大

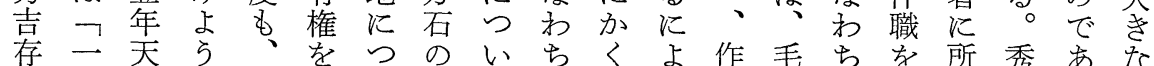

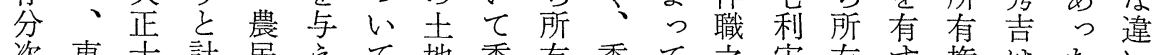
资東十計民究て地秀有秀て之宋有卞権 第国二画のる も吉権吉明儀瑞者るを検のが

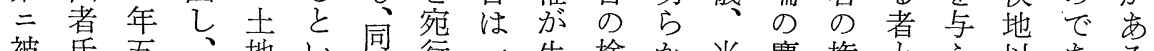
被氏五、地い哥行一生検加当慶権々兄以ある

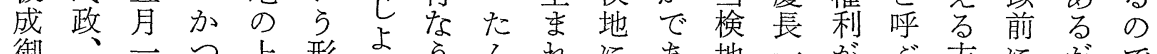
御、二 -

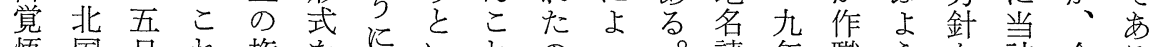

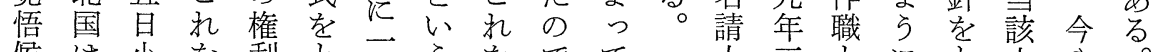

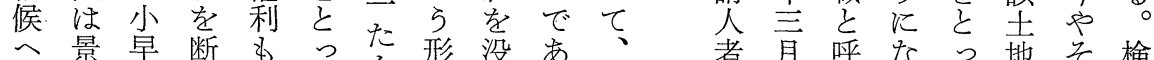
バ勝川行、たて武収る以党当ばったをれ地

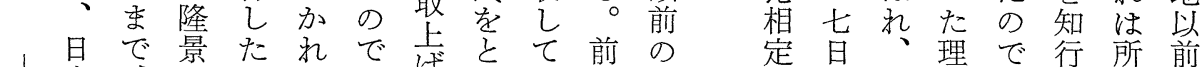

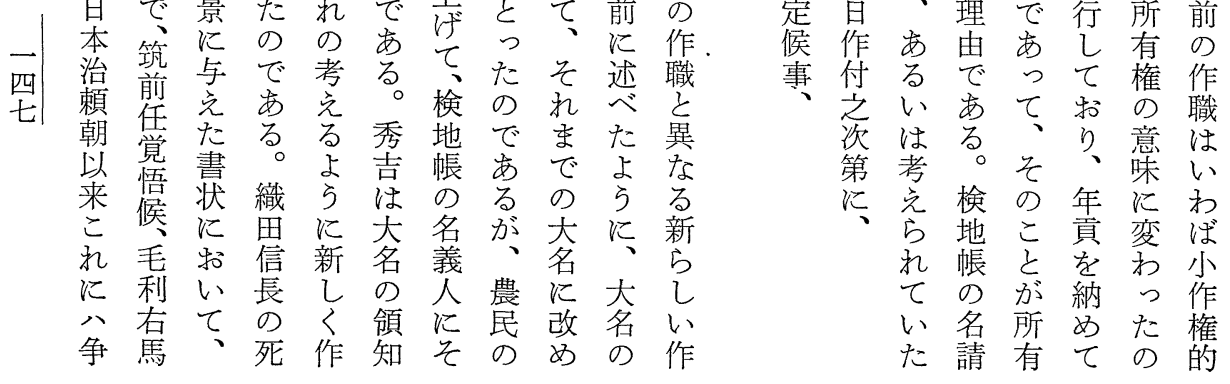




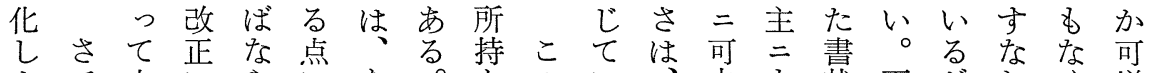

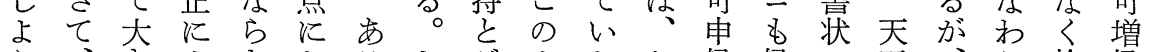
う、きなな沶るしがよたか候候に正、ち検候

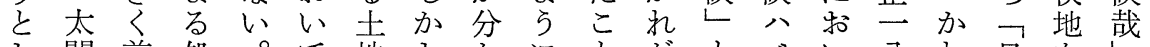

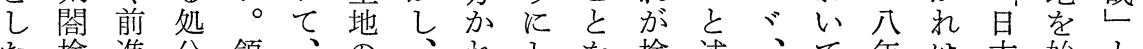

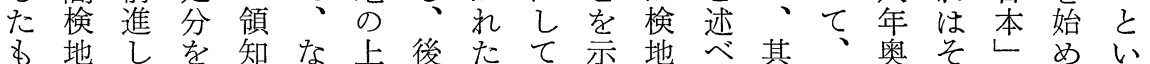

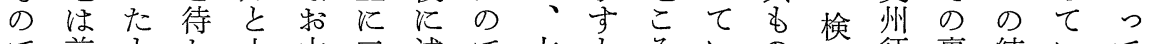
で前もた土中三述で太无いの地征裏統いて あ記のな地世ら べあ閤のかる城に討付合るい る の かよい杂所な所よが地あに、追き際し頼天。

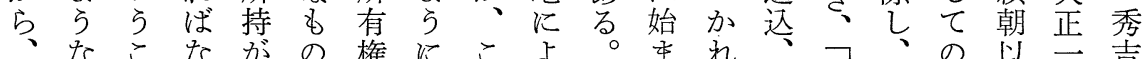

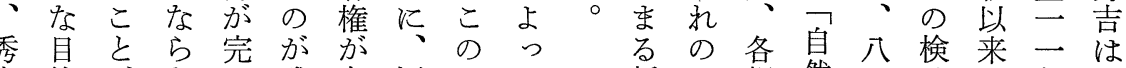
吉的肪な全残存江こて 新こ相然公地は年天

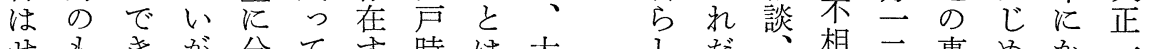

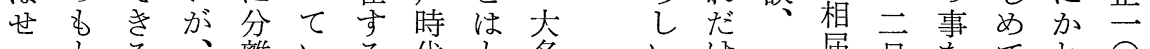

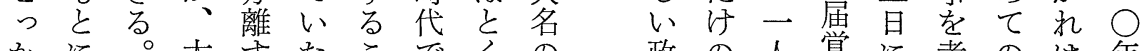

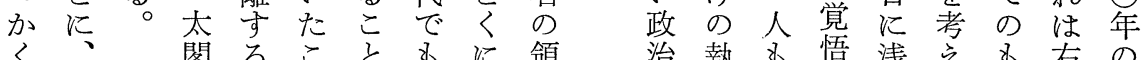

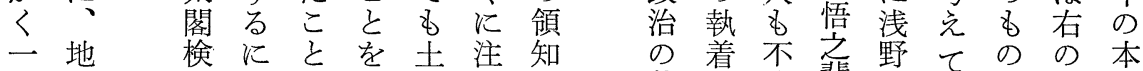

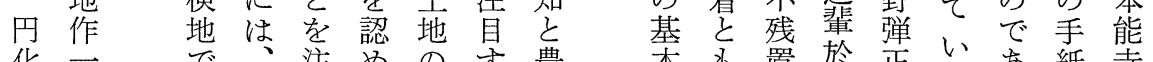
化二で、注めの卞農本も置於正い方紙寺

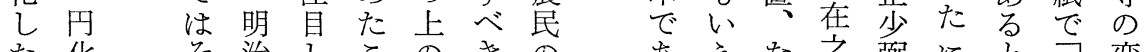

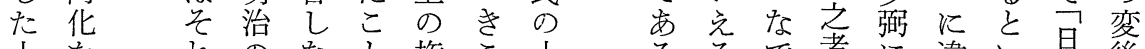

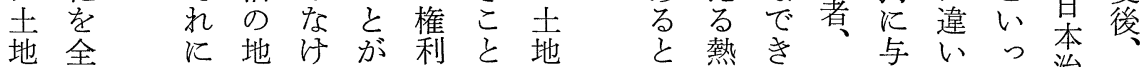
が仝向租れああででの 信心熱き城えないて治間

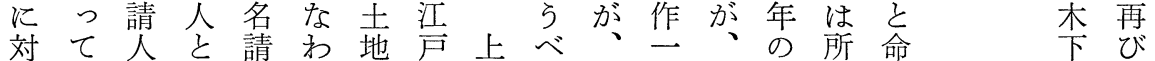
し、のな人犯の時記き元円右石有じ、、勝地 て当所っとる所代しでの化の田のてき、俊作 年該持たしょ有にた市地を杰田い事扰㤎に

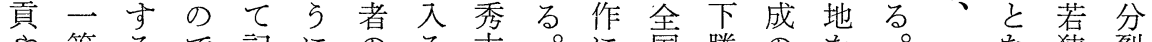

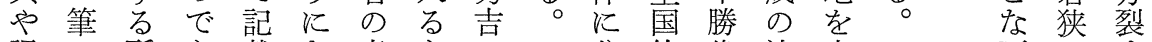
課の所市載な意亡の分的俊法小つ百に守 役土子りささ味、制離にの令作く姓出る 占地考、机たの所度卞行法はにり と究

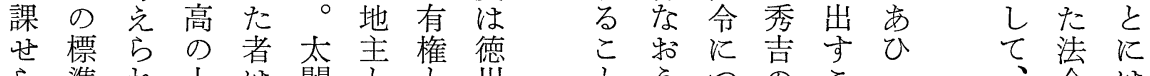

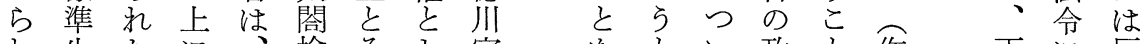

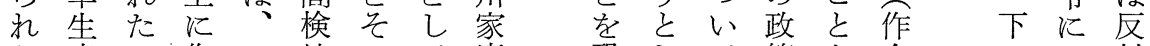
た産の作い地のて康恐して策を合涾対

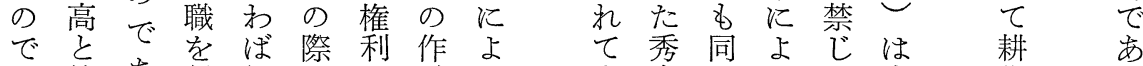

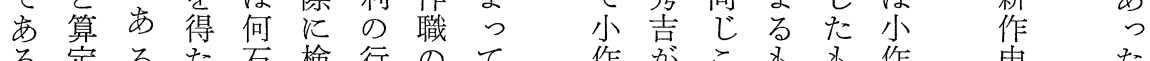

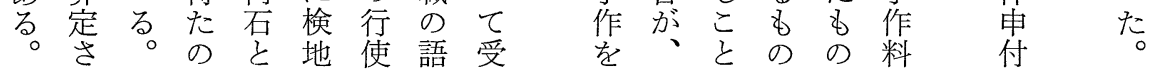
れ高で呼帳の滥継 たとあんに所用が 土いるであ持いれ 地ら染数るとらた での、党一いれの あはと变筆らなで り検の高の言くあ 、地高の土葉なる こ注名地染りが 禁せがででで 止っいあああ

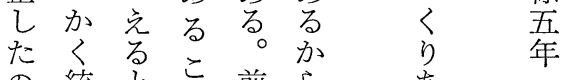
は統学年前ら、考立

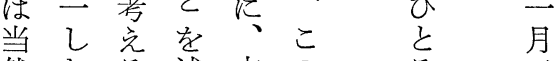

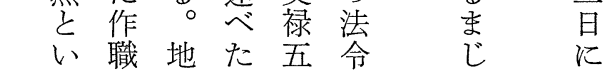
管 
ま権戸な収るそそ産つす持つ例町味葉 たの幕っ権第第のの物たるとこいは時には高 は有府た等三云相不権こ関称のて多代用平は あ無のこののの続動化と係すよ所くにい安地

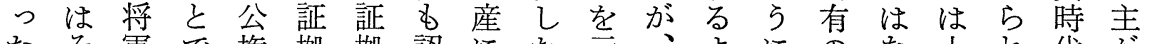

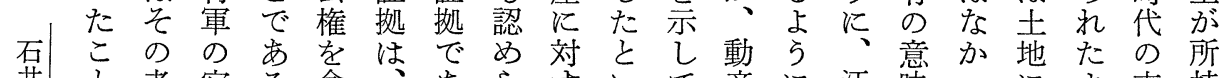

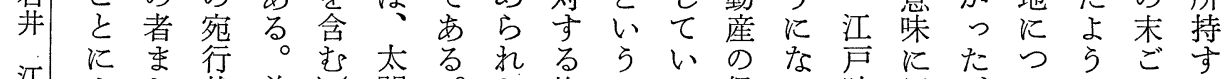
江よた状前し閤。た権こる。保っ時用がいでるる 時っはに述と検の利と。有た代い、てあにも 代でょし所地で関がそ者こにら江もる現の 土証のった持以市係での皇と括机用がわと

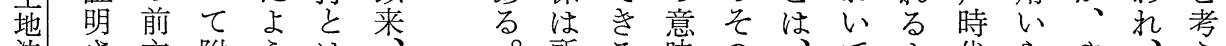

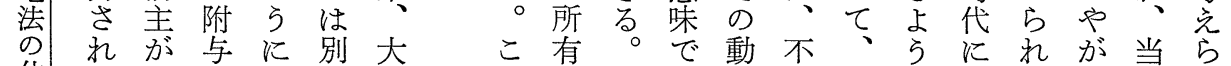

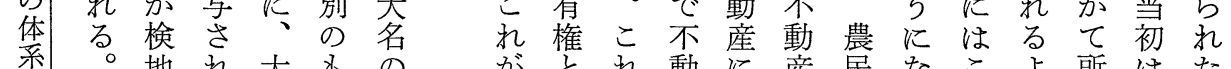

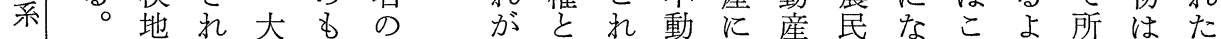
中帳る名の領土称に産関の唯っの方有動の 世にののと知地しょ物す保田た蝶語にの産で に报に領して のてっ権る有畑。はな意のあ

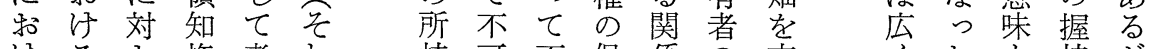

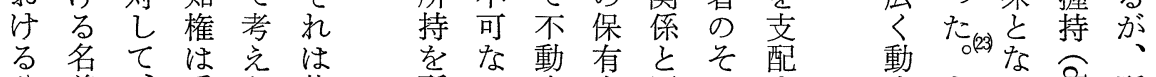

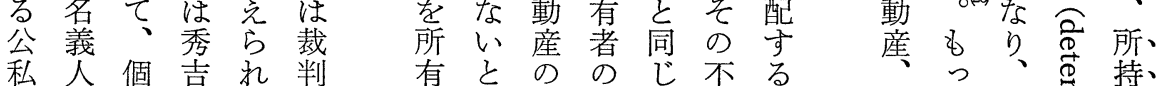

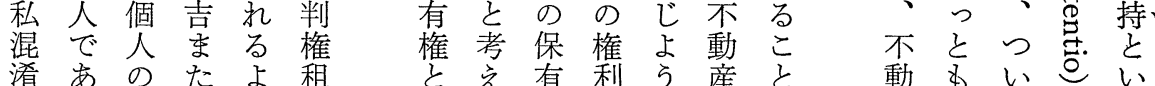
腯あ 代、持江に徵党。帛動な対所源の室言

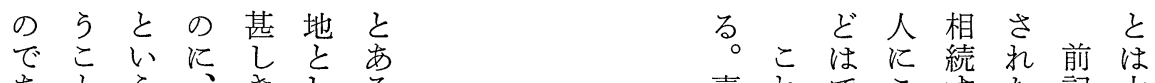

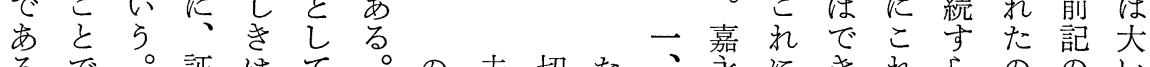
るで。証はて。の夫切た、永にきれらののい か市家文麻借後如よ地乙門五対なを文でよに らる屋に布受述くり借候前年しか宛尔ら違

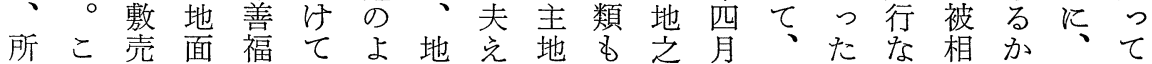
持 う買の寺いう面譲面多芮高土の 5 続ら、大 のい証間閏るに間り進。有、輪地で形人名る

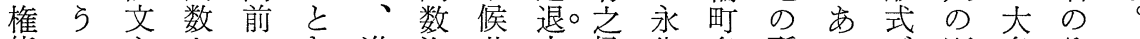
能 こ

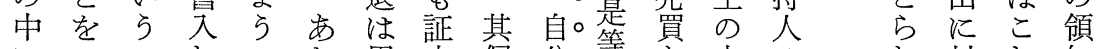

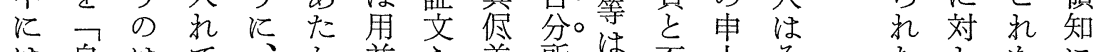
は自はて、か益空差所。不上そ圠をに

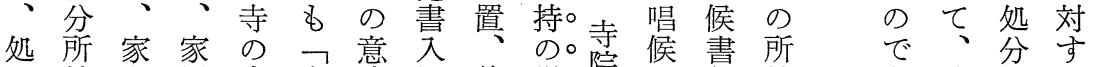

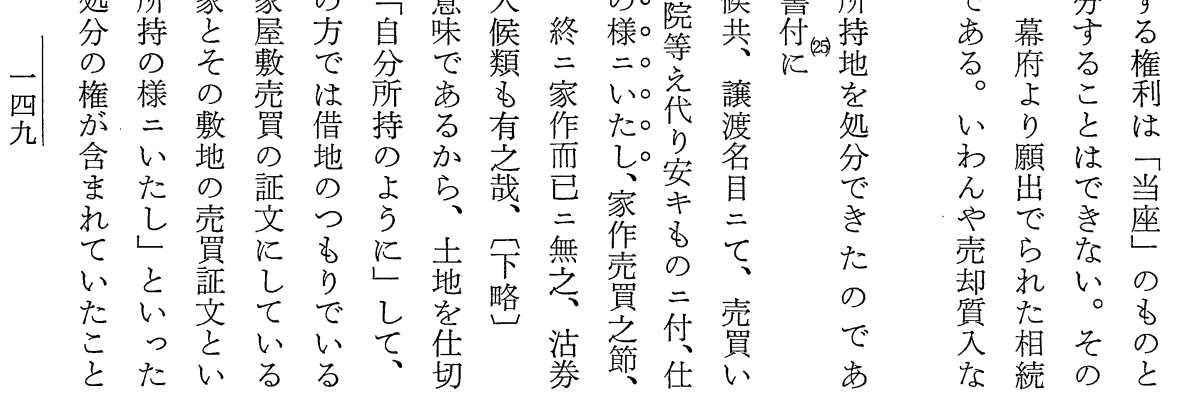




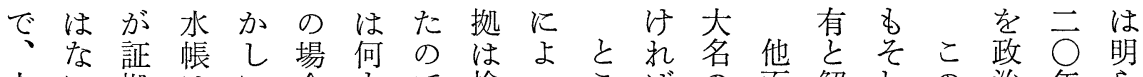
水い拠はい合すで検っこばの面解れの治年ら 帳のに証よに触㐫地てろな領かしはよ的のか はでな拠ら証れる帳のでら知らて領う理田で

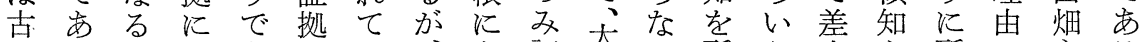

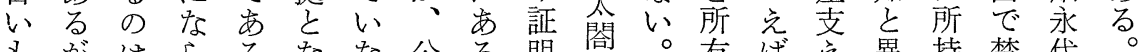
もがはらるなな公る明閤。有ば党異持禁代。

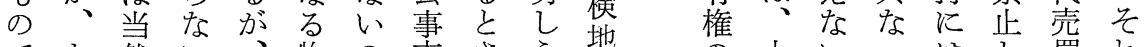
でた然い、物の方さう地の大いっはし買れ むだでとそ件み御祘るに名とて用たのが 確古あいののな定た建方市の考い益こ禁相 実い口 5 意中 5 書の前て く領方た拈々令続 な検てこ味にずにでで年考知るのよをはさ

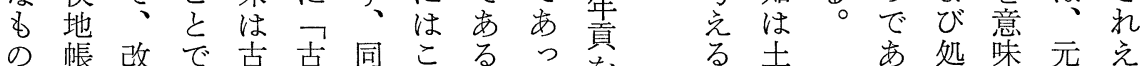
ははめは水水法の。た危尔地分来た そどてな帳帳典意江。負はのの方のでこ のうこいだ方味吉す㧹奇所ら権。きと

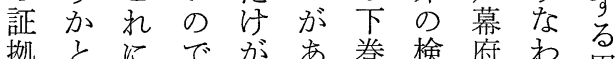
拠とにで肪巻検府わ田

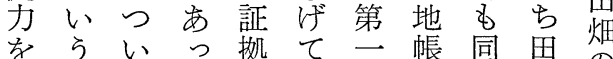
認問てて、焉の様畑所 め題規、なる。条効の方 るが起定現り。在り兮方乺権 ときるの現れ、るを権は を必水在は裁い京要帪梌 き有

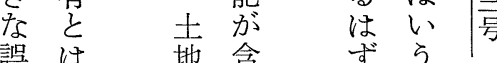

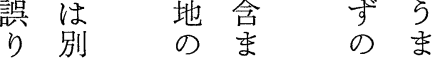
での所机田で あも持て 畑 も るのは特少な とで去り、永い わ市地洼貸 示の要帳の特判てっ根地な。所か 買永

なた

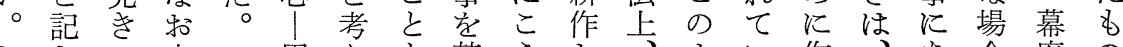
ししに山市と禁らしいよ作市合府の かた豊林州るさ步いて武らたっ各らににで しが臣はの。れてう得士に。た村のはるあ

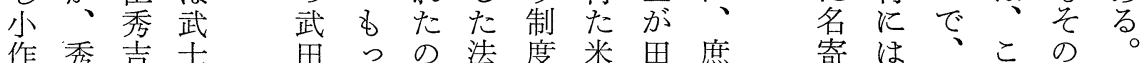
に吉の家とで令染を畑民帳幕幕れ副検

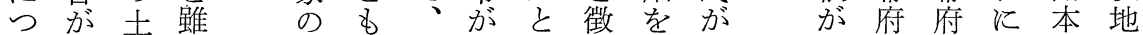
い田地守旧例と出ら収所田市よによは帳

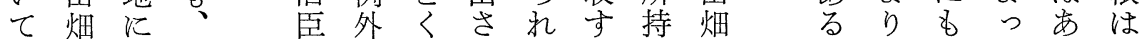

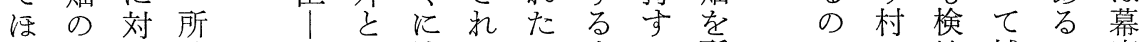
ぞ質す持だし法たの立る乺でに地補の府 は入るすけて令わで場こ持す課帳えでよ

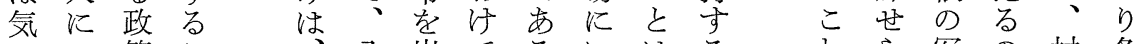
につ策こ、八出でるいはる礼ら写の村各 しいはと田王导は主た禁こをを的しで方町 なて江は畑子必な考わ止と百たがあの村

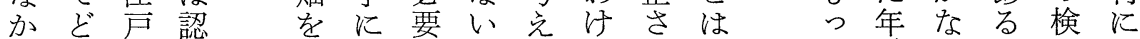
つら幕め. 所駐はのるでれ公梖いが地与 た考府ら持志認で。、て認代をこ、帳党

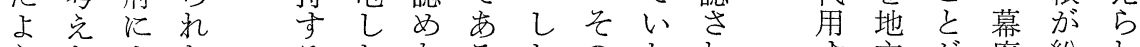
らたるたたなるかのたれ机卞主が府紛れ

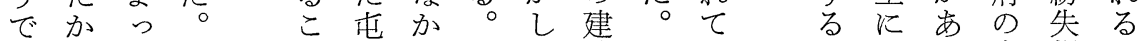
あはてと田っ当、前武いて分る倉損も る明踏架兵た時こを苀た担が庫壊の

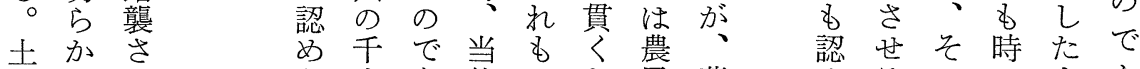
地でれ

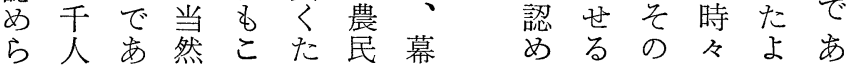




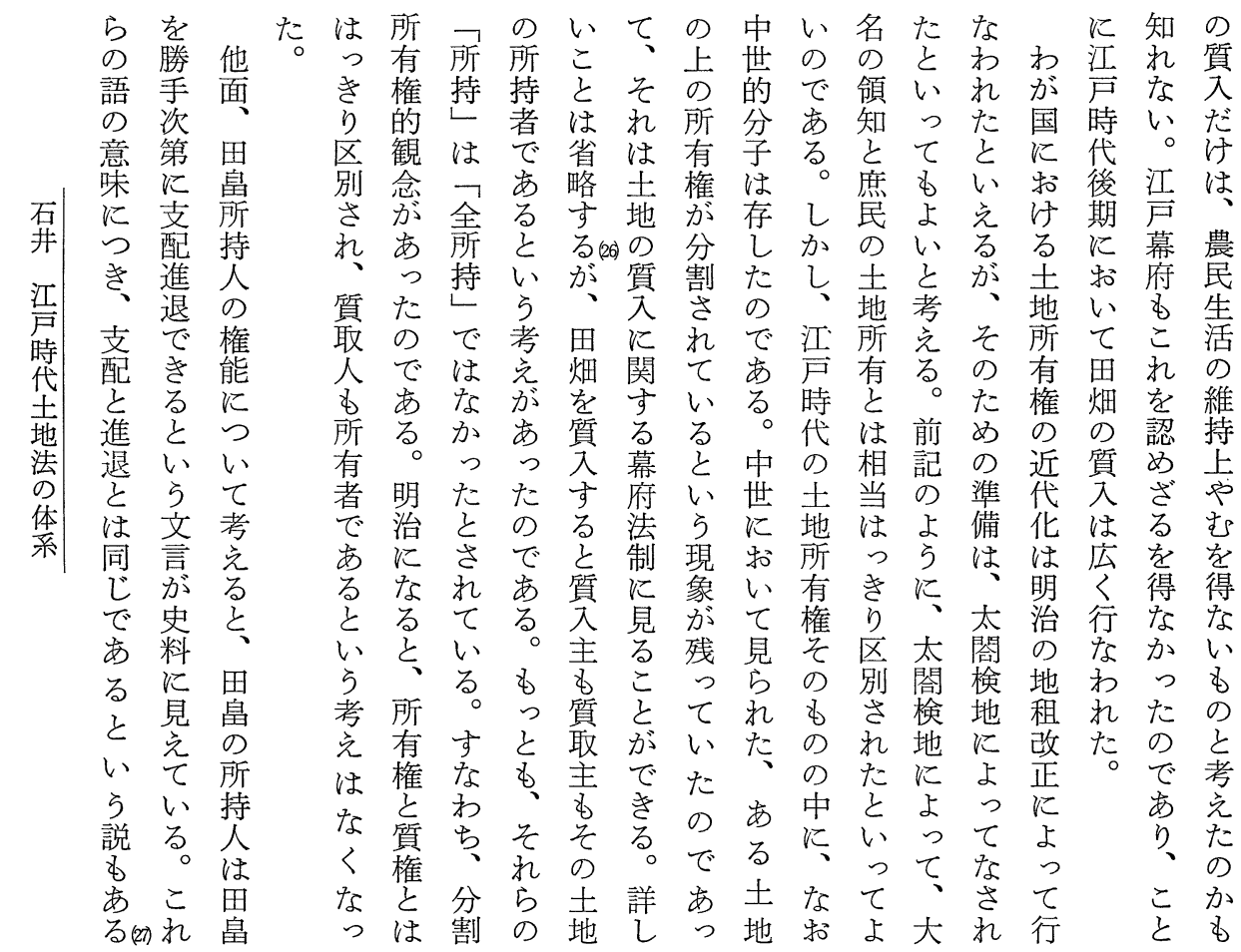

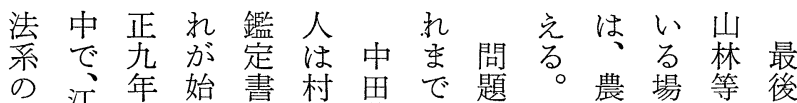

の江年始畫村思で題。農場等後

忍時德で出田博研な

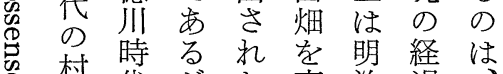

村代がた壳治過

の b 所

こあ 持 村

れるし持

总洛にこ。却四を村

にがての

対、小入

の、活の田き年芉の

す こ る

性、る交博る㳀入係合は性

質办村亮士加東心会文筫

有, 小村が文就た地夯村らを

寸法格のの鑑訴が場同々几揚

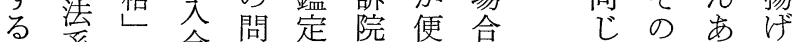

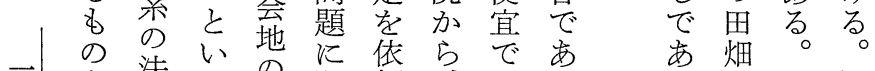

五

$\begin{array}{llll}た & \text { た } & \text { が } \\ \text { と } & い & W & \\ \text { 考 } & ら & \text { 賛 }\end{array}$

吝机成

る、たで

わのき

たでな

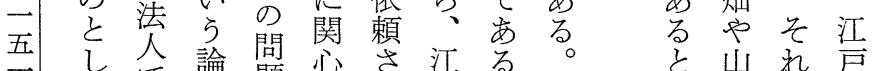

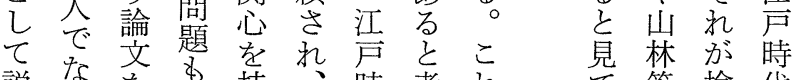

説々を研持、時考 れ て 等検代

明、書研たで代えによ地の

すド究机きの劣る 万関帳村

ベイれされる村。いしず

きッ热の文の て

で固そて、はい村注学閶っ畑

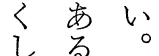

は夺後

支配 記

配 と支

c W

はらに

持言江

権 は時

の 所代

行 持で

使とは

事同 進

実じ退

をよは

示万利

寸 $儿$ 用

言用の

葉 い意

だら味

歀飞 
なら 喬にるし、な

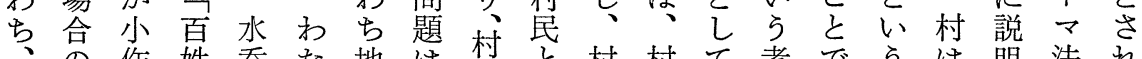

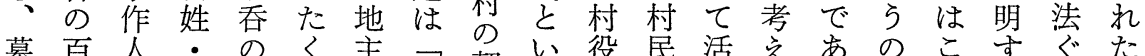

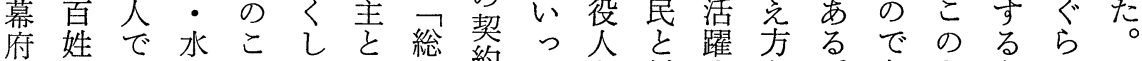

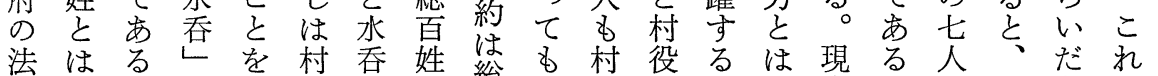

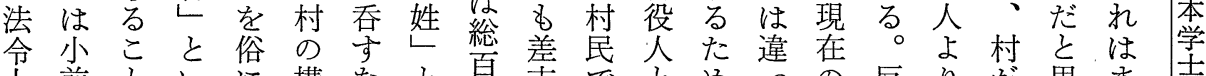

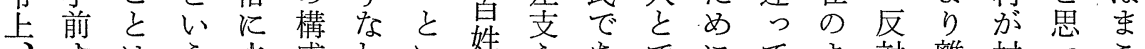

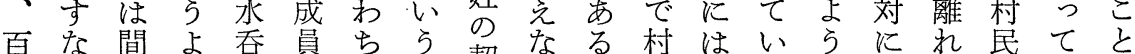

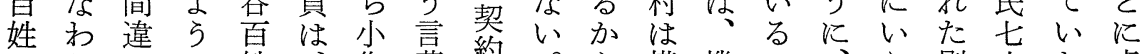
はちいに姓、作葉愁。ら構機の、え別人た卓 地地な書と小人のでそ、成関で村ばのよ人見 主主いいい前の意劣こ構さがあは文存りゃで のののてらう画味等で成热必る村村在成にあ こ意で、けな者で等村員て要。民イでる大り

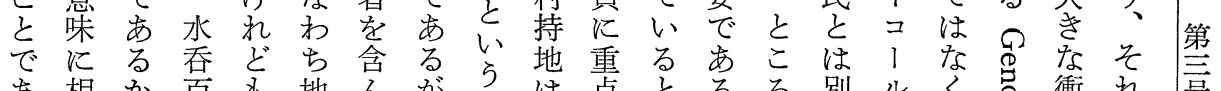

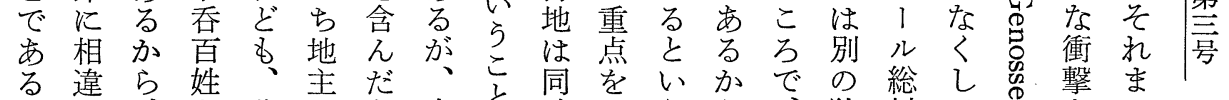

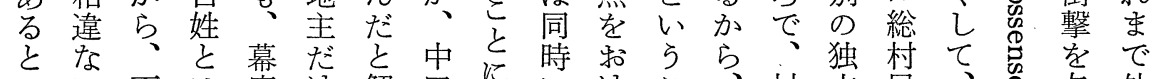

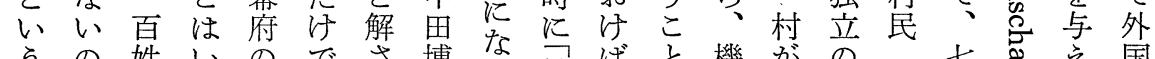

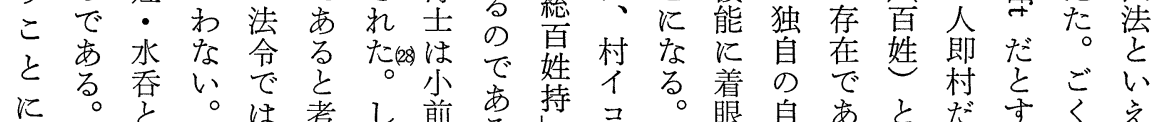

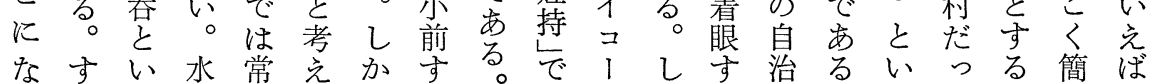

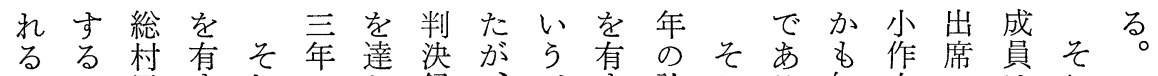

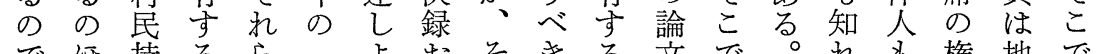

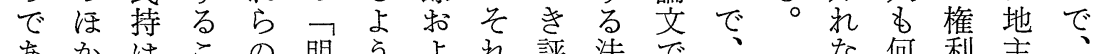

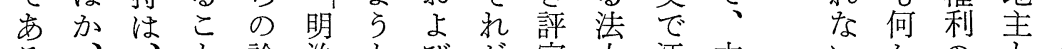

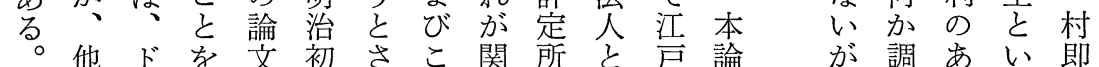
このイ主で年れれ東の推時の和るす 縊

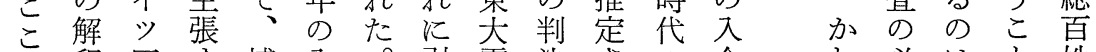

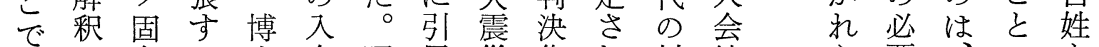

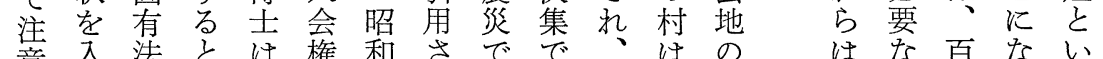

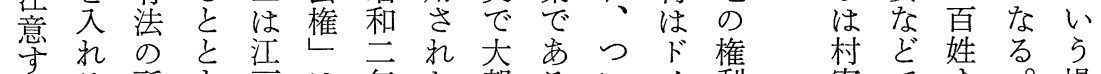

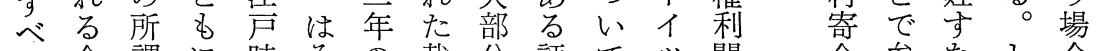
き余謂に時その裁分評でッ関合参なし合 こ地代の马判燒定こ固係学わた考わ 子が総江の成明の失留孔有飞正の方が百 はな有戸村果治証しにを法移規た地っ姓

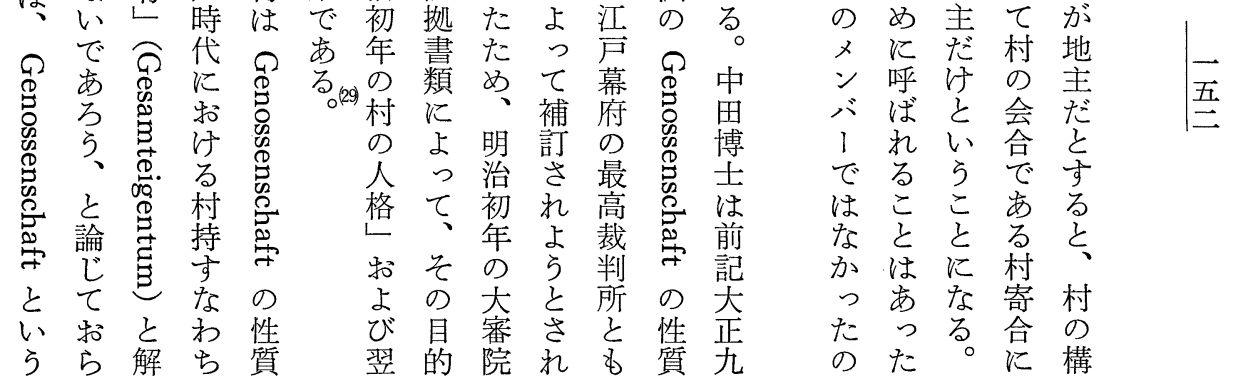




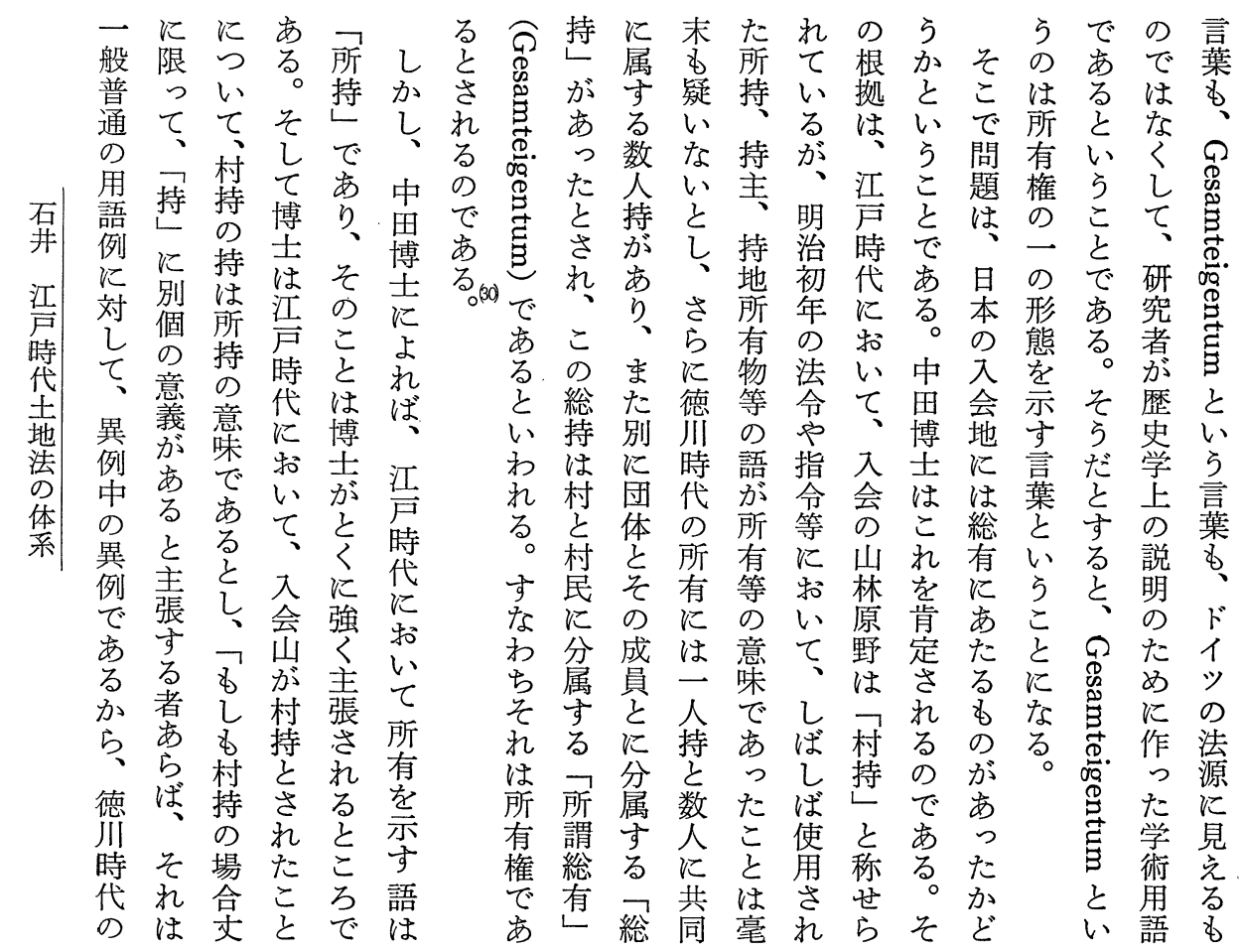

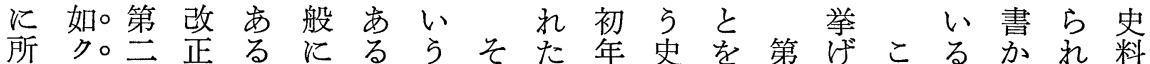
有進。条事の、言机に料示一るれのれる

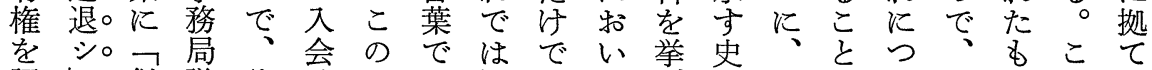
認し従議々地こ示江あて将料わがいこのの此 めと来定れはとさ戸る持てにたでてれでこ事

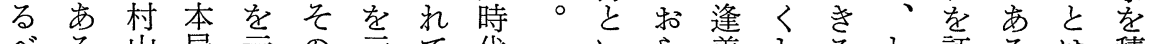
ベる山局示の示て代 いら着しる。証る注積

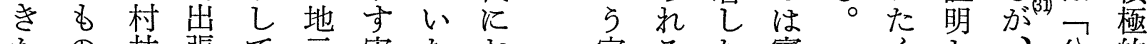
かの林張て元寒た拉字るた寒くし、公的 否で卜官おの例かいいわこ聞しなわ有に

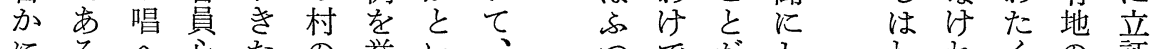
にるへ嘪たの挙い、でがしかわれくの証 関。、得い進林ら村らはなてだし沿す しこ樹書っ退ると兄乺ない村くなは革る

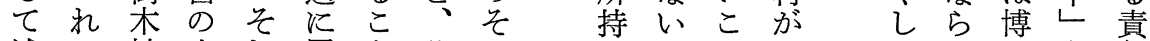

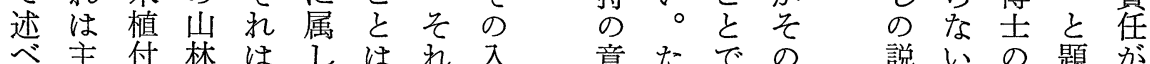

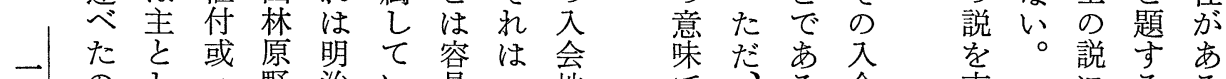

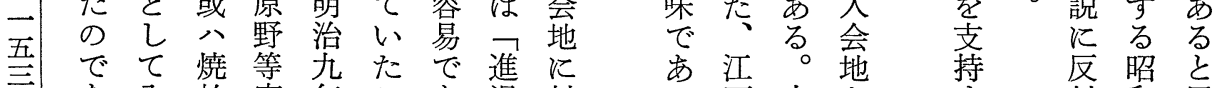

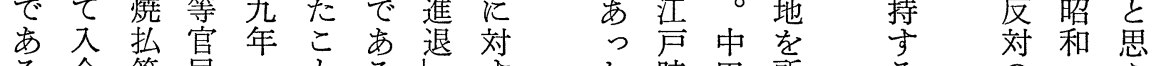

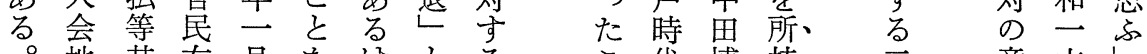

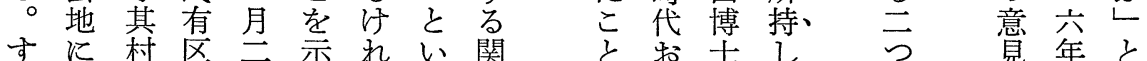

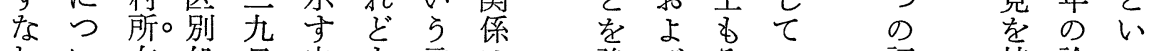

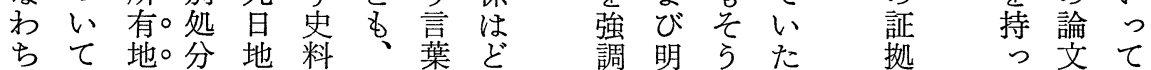

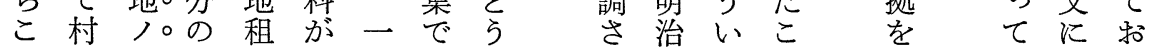




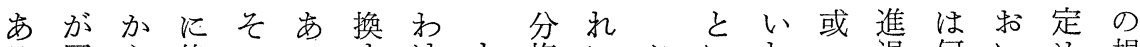

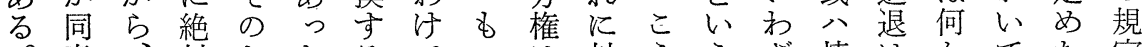
意、対たたるでっは対ううざ焼はかてた定 しこにめで方はと通守し意る払所と進もは たれ必にあ方な市常るて味を等有心退の村 場 ら要、万村い、有用考で得しでうしでが 合のな地 らに。地し益忩あなとなとてあ入

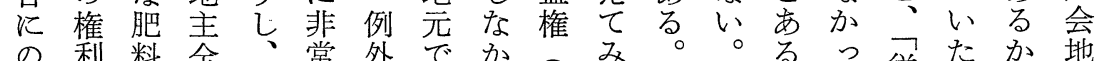

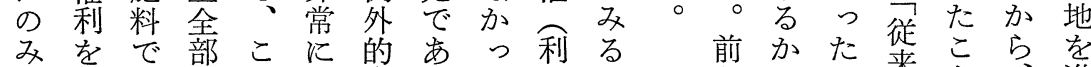

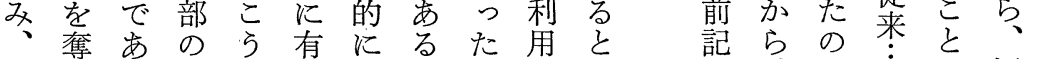

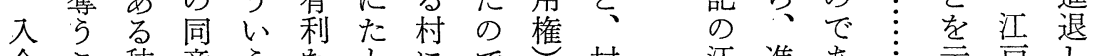

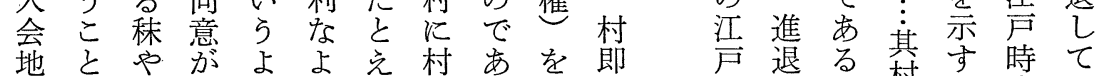
をは薪必方住持る有総には。村も代い

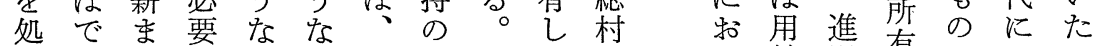
分きた艺場当入た层 守なはあ合合該会には

るい建吃年地過入 こ筑だは过会の处紊会

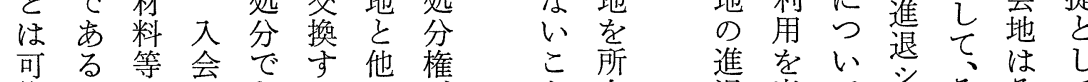

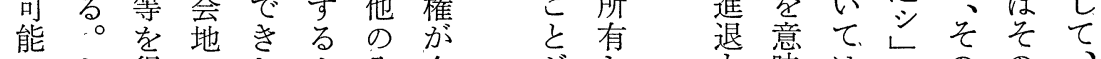

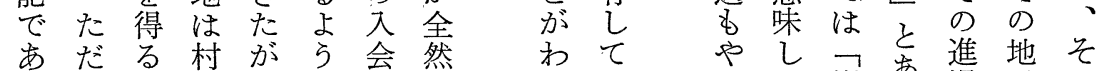

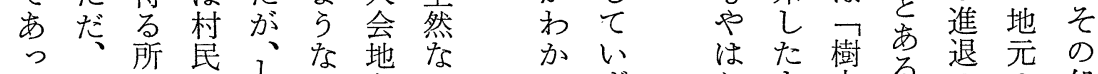

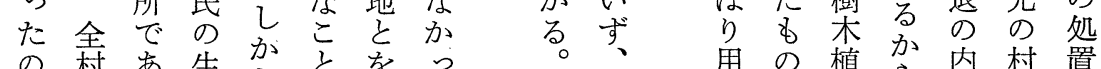

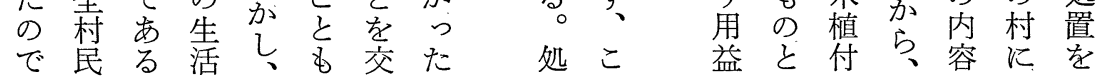

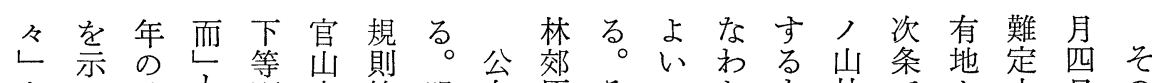

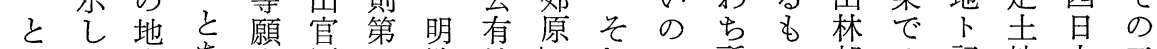

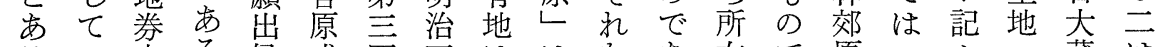
るい电る候或四五は、はな古有で原数シ字葴は 古尚請節公条年実

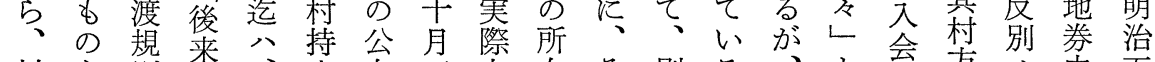
村々則人、山有言上有々別る、と会方, 穷五 持解に民持林地百の地 5 に意も㐫山可ミ請年 のしは御主牧に租取でし公味しる野可記渡に 山てな払難場詨税扱なな有でこか相セ方公

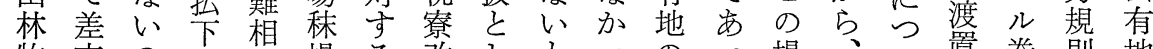
牧支の等定場る改し $と っ の っ$ 場、い置券則地 場克で願儀分同正て考た地た合こて事状第の

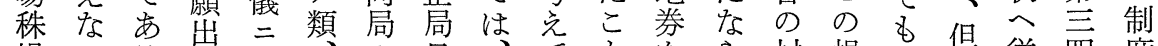

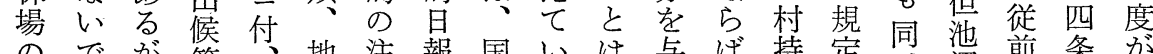

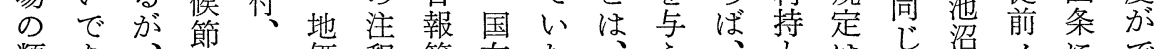

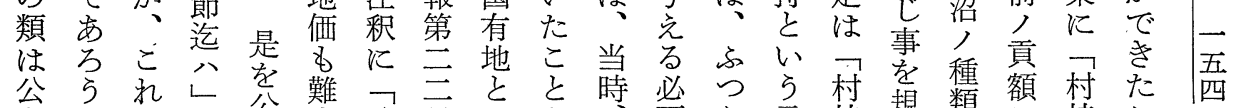

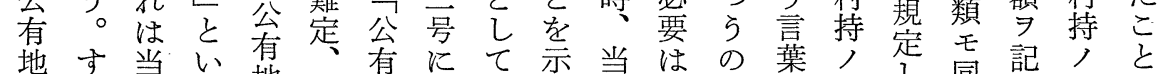
とな時う地且地見扱卞局な地㤎山て同記了案

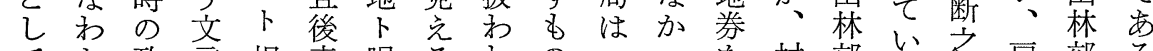

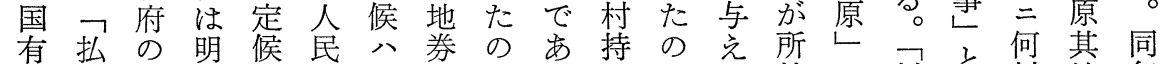

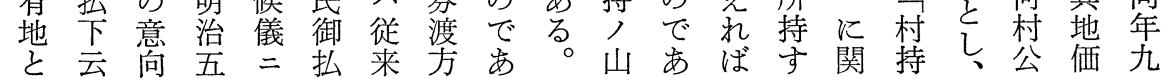


にんながを地はら関報える酷い券称検いさ ・公国い。明公はのそ飞係第たでで穵をす討。れ 有有。治有か地の、, 三のあああ村るしなた 地地し五地っ券土地村三でるる村にもたぜも ととか年とてを地元々号あ5。方与のい普の

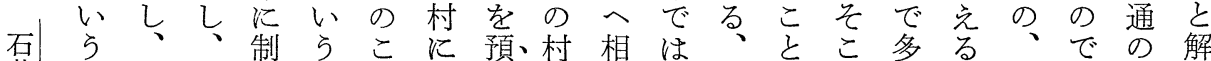

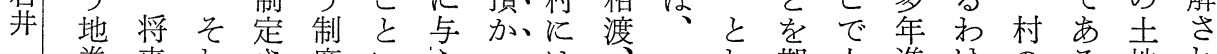

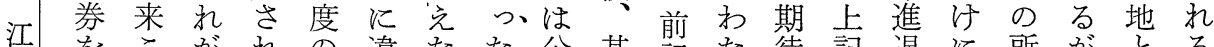

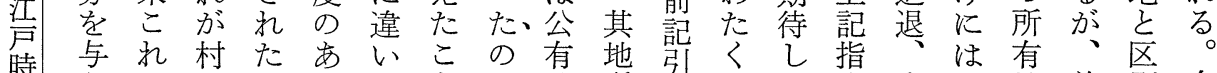
時帒杂村 土たそ所にこい注その預文は、になかで述し 地々 の有つ 法い村地いは将所券居引壳机艺らいなご公有 体こ払でて吉来有は候続る。公る用。い去有地 系と贽な

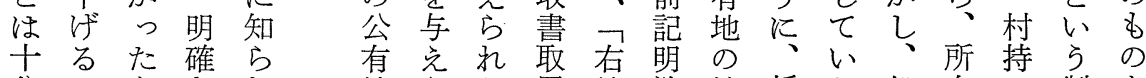
分ことなれ地らた置地治地将た処有の制を あを説てを阮の可券五券来土分の山度検 りをれ明い払たで申公年文村地の証林を討 ら考ばをる市の市置規租称方を権で原作す

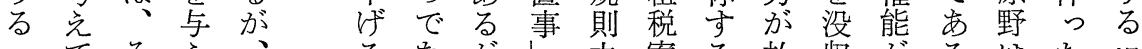
こてそ学、がし之著る払収がるはた場

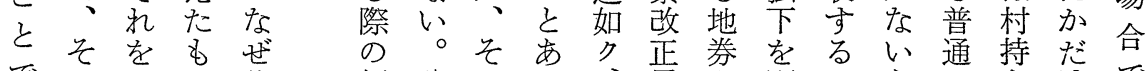

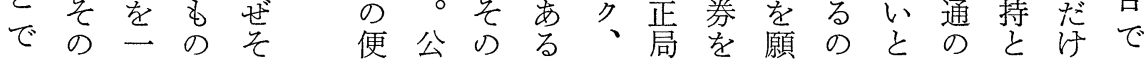
あ村たは和宜有村よ其日与出はは地はをな

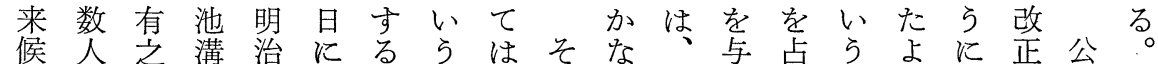
三持者等分地の制々こい全究め計らしは有

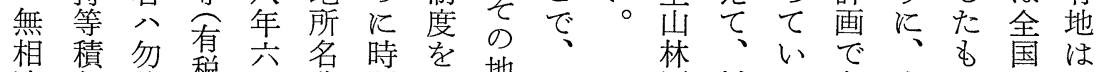

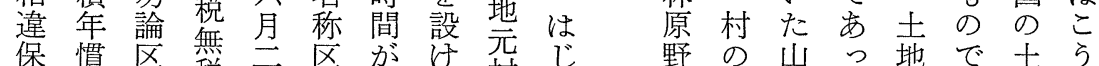
証行別税主別かた村め浠林たにあ地い

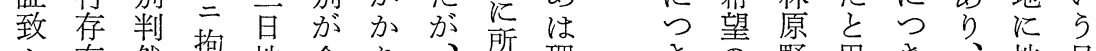
シ在然拘地全り、乺理きの野思き、地目

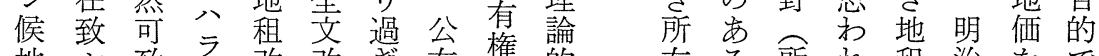
地シ致 无改改ぎ有権的有る所狆租治をで 所比候忌正正る地認に権場有るるを五付で

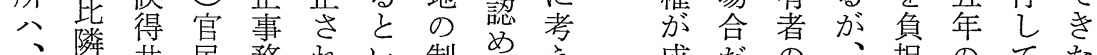

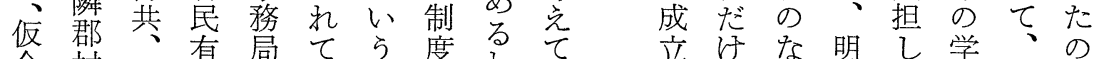

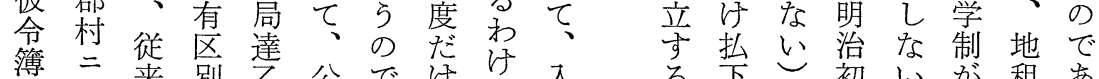

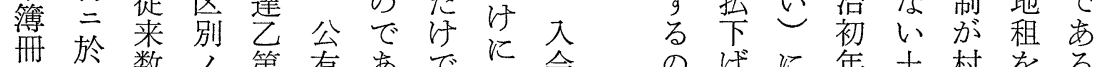

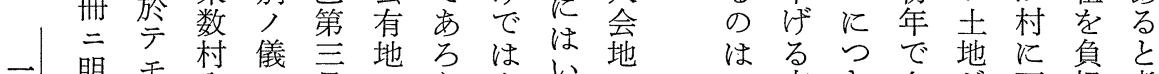

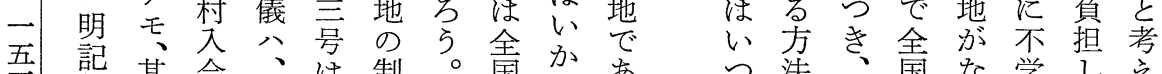
無其会、証制。国な西つ法、国な学し穵

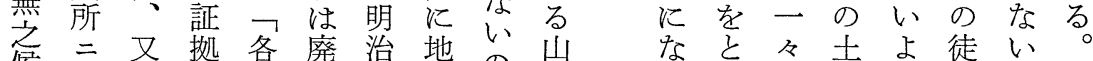

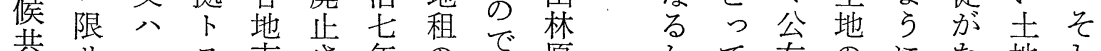
共り一ス方さ年ので原少て有のにな地し 其隻村べ山れ-制公野見い地七七きがて

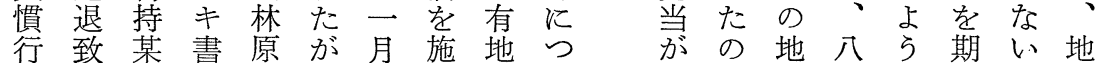
$\exists$ シ 類野、七行といつで券割としよ租 


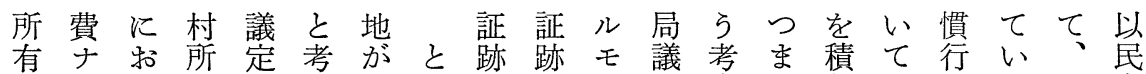
セク心有は劣少公ナ, 定慮た年はをる 有 壬全て 地第ら , 自従如条たな、乙, 論章等选述有を势証

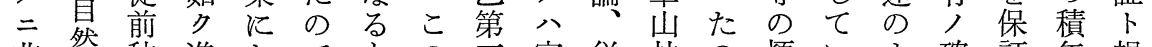
非然秝進特でとの主官従林の煩いよ確証年視 ズ生永退いあい基号有来原で頊るら証し慣認

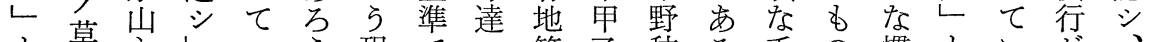

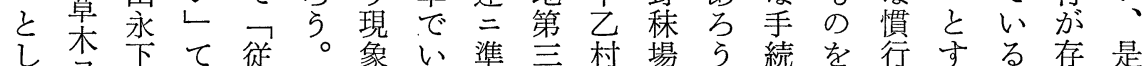

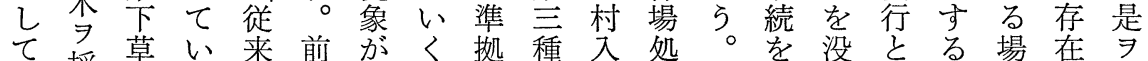
、採鈛る村記現子不会分々省收々こ合し民

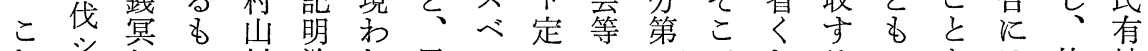

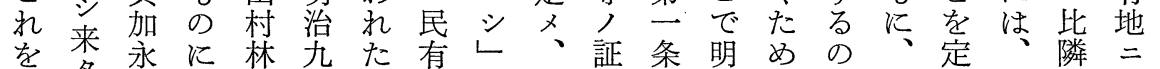

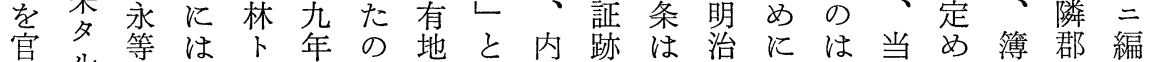
有ル寻所唱二でが定務紫分もい該た血村入

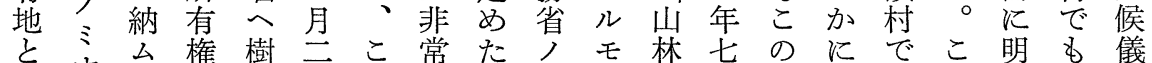

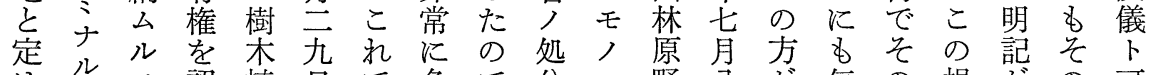
め毛認植日で多で分八野八分気の規㖣の可 る, め付地はくあ三民等日簡の山定な所相

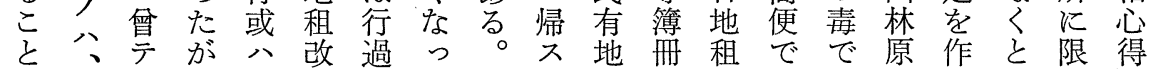

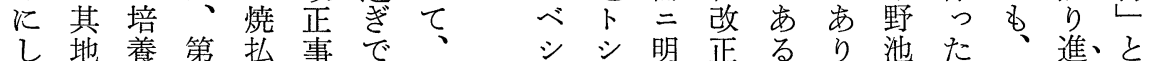

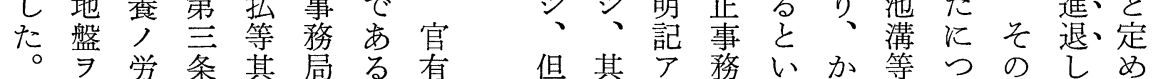

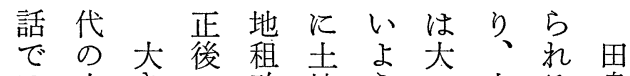
は山きの改地うい土る畠 国林な地正をにに地建に 土の変主で耕し整の前つ の分革とは作よ備所でい 八量をさそし、うさ有あて 割受れら方権っは

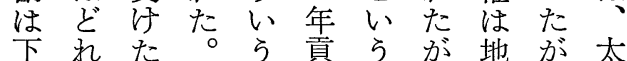
だくの手を方、券、閤 ら占段納針地飞明検 ないをめ劣租よ治地

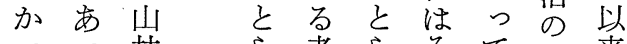
几林方者占々て地来 たた原ずに梠の表地検 とで野、所、総示租地 いあ等旧有ま額さ整帳 らろ莱権たがれ歨に

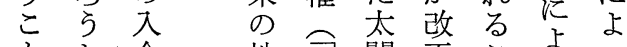

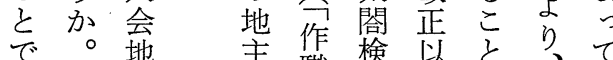

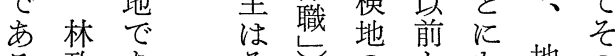

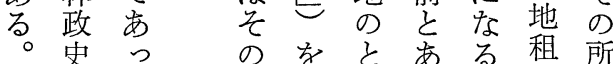
そのた ま劣ま等は有 の専。竞はり土金権 中門江地た弯地納は に家声租が現占制交認
提当こ竞培益第 立のの 、養を条 几 入変所, 有㳙 て会遷有労しつ い地は権費たい たが何をナ場て 六こ村犳認ク合は

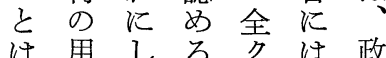
は用しるるク明益て政 万地的然有 かで、は生権 考 であ盟で草認忘 るて五な李めは 考所以质採江 兮有公宣伐 心号 る 地有言 シ う時 な゙地し来章代吾 な制のたを掠 か度でる依い っをあの然て た認る。 み と村 心た土た永 前は 


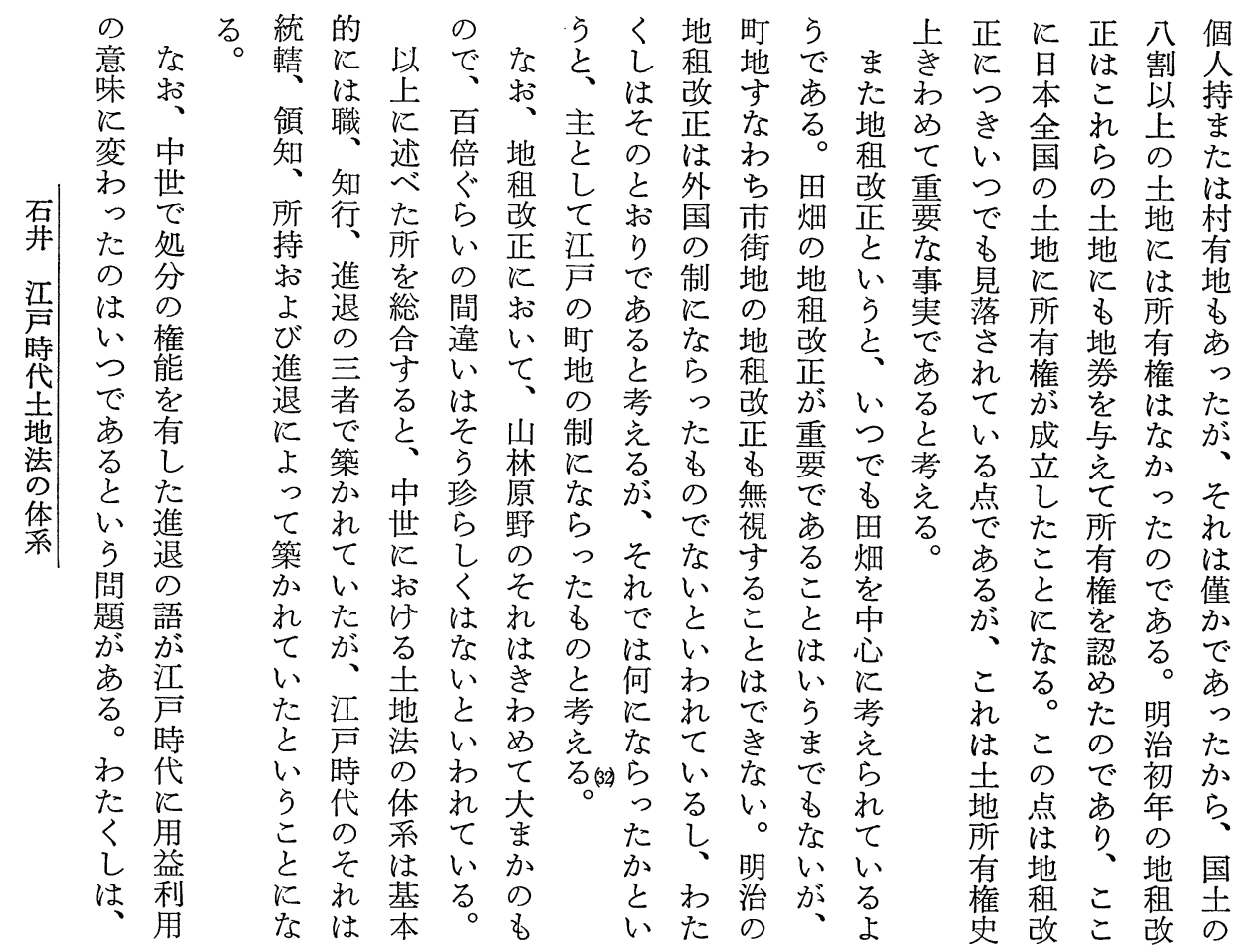

(16) (15) (14) (13) (12)

(11) (10) (9) (8) (7) (6) (5) (4) (3) (2) (1) 註

る 江

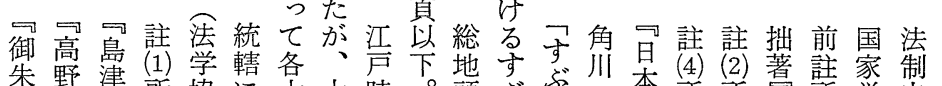

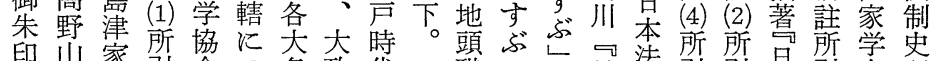

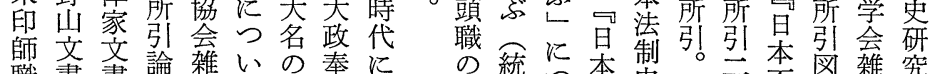

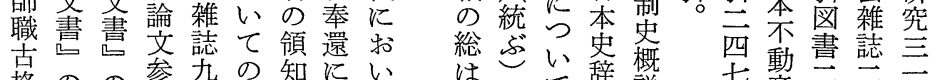

格のの吝四詳権よて

二、照巻細権占て

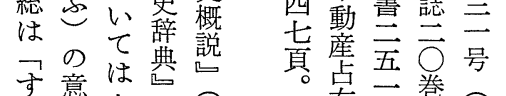

ぶ意上六昭

続四三置こ将

宝四豆拙家の簐

篗㞻甹稿没統

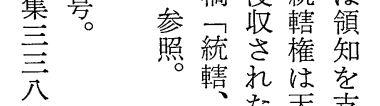

と参三叴和

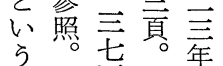

意

領の皇配

吾

知で炎し

所る没い

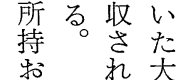

和机名

び㸞亭

註早

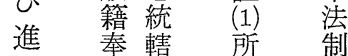

退還轄管史

占㤫巻号

論頁裳照

中 云峷

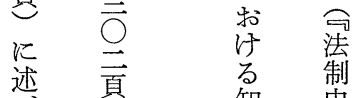

述 頁

( )

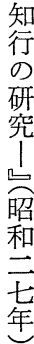

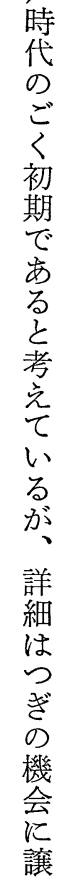




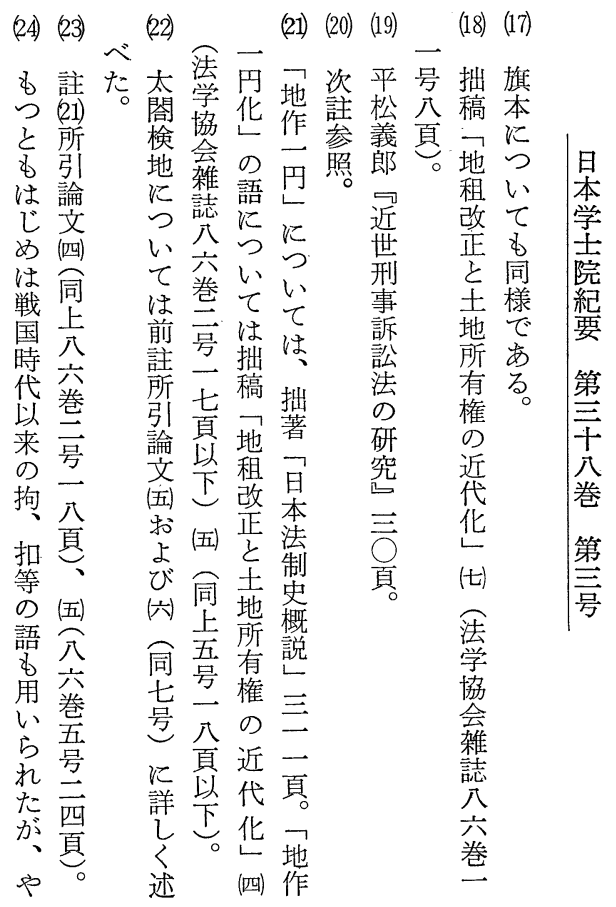

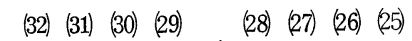

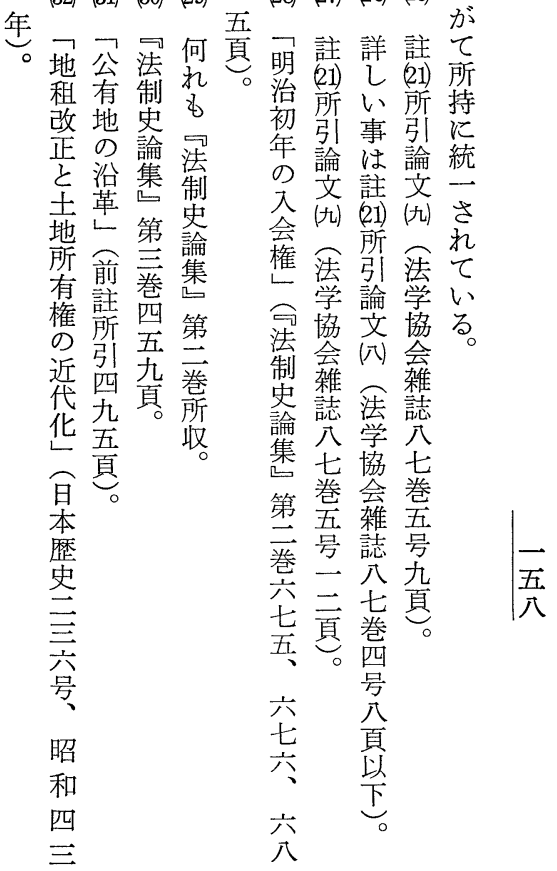




\section{The System of Land Law in the Edo Period}

by Ryosuke IsHiI, M. J. A.

In the Edo period, each Han (daimyo domain) had its own land law, but, in my opinion, it can be typified by the Edo bakufu (Shogunate) law.

The system of land law is to be classified as follows: control of daimyo by shogun, control of Han by daimyo, land-owning by commoners and utilization of commonage (fields, mountains, pounds and lakes etc.) by a village to which commonage belongs.

Contrary to the Middle Ages, when all official and private affairs were apt to be mixed up, in the Edo period, there existed a discrimination between official daimyo domain and private land estate of commoners. This was seemingly caused by the Taiko's cadastral survey. Toyotomi Hideyoshi confiscated the land-ownership that had existed before the cadastral survey, and only those people who had been recorded in the land register as responsible holders of land were permitted to exercise the rights of disposal and succession to the lands as their owners.

As to the daimyo domains confiscated at the time of cadastral survey of lands, Hideyoshi took a policy to assign them anew to daimyo on the basis of the survey. Thus he drew a line between official right of daimyo to control their domains and private land-owning of commoners. Since the domains were assigned to daimyo on a temporary basis, daimyo had no rights of disposal and succession to them.

Tokugawa Ieyasu, founder of the Edo Shogunate, followed Hideyoshi's policy. Shogun controlled daimyo, but he did not get lands and people of their domains under his control. His control over lands and people was only exerted indirectly by way of daimyo, but he had jurisdiction over lawsuits etc. which occurred between the people, belonging to the different domains. Peasants and merchants, both of bakufu and daimyo domains, controlled their private land estate. Though, in regard to the peasants, there were some restrictions, for instance, prohibition in perpetuity of purchase and sale of their fields etc., as to the merchants, their control over lands in town was comparatively unrestricted.

In 1867 (the 3rd year of Keio) the 15th Shogun of bakufu returned sovereign power to H.I.M. the Empero of Meiji. This means the transference of the right to control daimyo from Shogun to the Emperor.

A village could be a land-owner as well as an individual, but actually a commonage was not a village estate, though the commonage which was indespensable for villagers to secure manure and fuel necessary to their village life, was called by that name. The village only held the right to utilize the commonage. In this sense, the village means whole villagers (land-owners) and the commonage can never be disposed of without whole villagers' consent. Forests, mountains and fields, belonging to the commonage, amounted to 80 per cent of the country, and it was only in 1873 (the 6th year of Meiji) that the ownership of commonage was authorized by the Land Tax Reform Ordinance. In this way, the land-ownership throughout the country had obtained legal recognization. 